\title{
Can Changes in the Cost of Cash Resolve the Corporate
}

\section{Cash Puzzle?}

\author{
José Azar, Jean-François Kagy, and Martin C. Schmalz*
}

February 14, 2014

Preliminary. Comments welcome. Please download latest version.

\begin{abstract}
To answer this question, we first create a measure of the opportunity costs of holding liquid assets as the wedge between the cost of capital and the return of firms' cash portfolio. Exploiting both cross-sectional and time-series variation of opportunity costs, we estimate a negative effect of opportunity costs on the cash-to-assets ratio of U.S. nonfinancial Compustat firms. We then use the estimate to predict changes in aggregate cash holdings for 1945-2013 and find that they closely match actual changes in cash holdings over that period. Differences in opportunity costs also explain cross-country differences and within-country time variation of cash-to-assets ratios of firms in the five largest European economies and Japan. The increased sample length for the U.S. results and the international results make clear that current U.S. cash holdings are not abnormal, neither in a historical nor in an international comparison.
\end{abstract}

*Azar: Charles River Associates, jazar@crai.com; Kagy: Cornerstone Research, jkagy@cornerstone.com; Schmalz: University of Michigan Stephen M. Ross School of Business, schmalz@umich.edu. For helpful comments, suggestions, and discussions, we would like to thank Thomas Bates, David Denis, Amy Dittmar, Robert Dittmar, Ran Duchin, Antonio Falato, Joan Farre-Mensa, Mike Faulkender, Charles Hadlock, Kathy Kahle, Mark Leary, Stefan Nagel, Uday Rajan, and seminar audiences at Brigham Young University and the University of Michigan. All errors are our own. 


\section{Introduction}

What explains the secular variation in corporate cash holdings? A large literature has evolved around this question, involving corporate finance researchers, policy makers, and investors. Policy makers wonder what they can do to make firms spend their cash instead of hoarding it $^{1}$ and some investors believe they can increase firm value by making firms reduce their cash holdings. ${ }^{2}$ In response to this vivid debate, corporate finance researchers have investigated a wide range of explanations for why the benefits to firms of holding cash may have increased so much in recent decades. ${ }^{3}$

By contrast, we investigate whether changes in the opportunity costs of holding liquid assets (as opposed to increases in the benefits of holding cash) can also explain the timeseries changes in the level of liquid assets held by the nonfinancial corporate sector. ${ }^{4}$ Figure 1 illustrates that difference in approaches in the context of the framework of Opler, Pinkowitz, Stulz, and Williamson (1999). The literature has correlated the increase in the corporate cash ratio since 1980 with variables that have been hypothesized to shift the liquid assets demand curve (Figure 1(a)). By contrast, we argue that the increase in the cash ratio between 1980 and 2011 - as well as the decrease between 1951 and 1980 - can be explained by shifts in the opportunity costs of holding liquid assets over time (Figure $1(\mathrm{~b})) .^{5}$

\footnotetext{
${ }^{1}$ See, e.g., Sanchez and Yurdagul, 2013.

${ }^{2}$ See, e.g., Carl Icahn's letter to Apple CEO Tim Cook in Steven Russolillo's recent article in the Wall Street Journal (Russolillo, 2013).

${ }^{3}$ Existing explanations for the increase in firms' demand for liquid assets, reviewed in section 2 below, include tax motives, increasing R\&D and cash-flow volatility, increasing focus or decreasing diversification and operational hedging, and rising intangible capital.

${ }^{4}$ The cost of holding cash differs from the cost of getting cash into the firm. The latter is typically an important driver of cash holdings in structural models of cash such as Riddick and Whited (2009) or Nikolov and Whited (forthcoming), while the cost of holding cash is assumed to be constant over time in these models. We investigate the impact of changes in the cost of holding cash alone.

${ }^{5}$ Our measure of opportunity costs also predicts the secular increase in cash holdings 1920-1950 documented by Graham, Leary, and Roberts (2013). However, the data have not been released for public use.
} 
We start by calculating the opportunity costs of holding cash as the spread between the nominal T-Bill rate (the cost of capital for holding cash in risk-free assets) and the return on the corporate sector's liquid assets portfolio. The measure strongly correlates with nominal interest rates (see appendix figure B.1). We find two main reasons for the existence and time variation of this spread. First, especially in the earlier parts of the sample, corporations hold a substantial fraction of their liquid assets portfolio in non-interest-bearing currency (i.e., coins or paper "cash") and checking accounts, possibly because converting interestbearing assets into cash used for transactions was costly and time consuming. In 1980, this fraction was $50 \%$. As a result of this portfolio choice, the return on the firm's cash portfolio is typically lower than the cost of capital for the project "holding cash." Because the cost of cash correlates with the nominal interest rates while the return on non-interest-bearing assets does not, the opportunity costs of holding cash covary positively with nominal interest rates. In particular, the opportunity costs were much higher in the inflationary period around 1980 than it is today. ${ }^{6}$ As a result, a corporate CFO had much stronger incentives to economize on cash held in non-interest bearing accounts in the period characterized by high inflation and nominal interest rates around the year 1980 than either before or after.

A graph of the opportunity cost and the U.S. corporate cash-to-assets ratio for the period

\footnotetext{
${ }^{6}$ The wedge between corporate and personal income taxes on interest income, as discussed in Graham (2000) and Faulkender and Wang (2006), creates a second reason for a cost of holding cash. This disadvantage scales linearly with the level of nominal interest rates and therefore exhibits similar dynamics as the first reason detailed above. However, changes in the wedge will not explain the time series of cash holdings. Marginal federal tax rates on personal income were much higher than the corporate tax rate from 1945 until the mid-1980s, then were roughly equal, and dropped considerably below the corporate tax rate only with the 2003 tax cuts. This monotic decrease in the wedge of personal minus corporate tax rates can of course not explain the non-monotic pattern of cash holdings between 1945 and 2013. In the cross-section, the effect of personal and corporate taxes on firms' optimal cash holdings is difficult to assess because of the complications from calculating the effective marginal tax rate of both corporations and individuals, statelevel differences in income taxes and a not perfectly observable geographical distribution of stockholders, etc. Lastly, tax explanations affect only the portion of cash invested in interest-bearing assets, and are therefore by construction a second-order effect compared to the costs of cash arising from corporations investing in non-interest bearing assets.
} 
1945-2013, calculated using Fed flow of funds data and presented in Figure 2, suggests a strong negative correlation between the two time series. The opportunity costs of cash started at a low level in 1945, increased, and became particularly high in 1980, and then decreased again to reach near-zero levels by 2011. Corporate cash holdings followed the opposite pattern. (The "corporate cash puzzle" refers to the increase of cash in the final 30 years of that time series.)

We formally estimate the effect of the opportunity-cost measure on firm-level cash holdings using Compustat data from 1980 to 2011. We control for firm-level characteristics, firm fixed effects, and a nonlinear time trend. The latter implies that our identification comes from variation of cash holdings and opportunity costs around their trend and not from the secular time trend in cash itself that we will later attempt to predict. In dynamic specifications, we also include lagged values of cash-to-assets ratios. In all specifications, we find that the opportunity costs of holding cash have a negative and statistically significant effect on corporate cash holdings that is comparable in size with estimates from the existing macroeconomic literature on money demand. In particular, we estimate that a one percentage-point decline in opportunity costs increases cash to asset ratios by approximately $15 \%$, or that a 5 percentage-point decrease of opportunity costs increase cash holdings by approximately 103\%. As opportunity costs declined by approximately six percent from 1980 to 2010, it is evident that the estimates have the power required to explain why cash holdings increased by a factor of more than two between 1980 and 2010. The results hold across industries and subsamples sorted by firm characteristics. Any differences in point estimates across subgroups are not statistically significant.

To investigate the power of these estimates to explain the dynamics of U.S. corporate cash holdings also at intermediate points as well as before 1980, we apply our estimates for the 
effect of the opportunity costs on cash holdings to the observed changes in opportunity costs for 1945-2013 to calculate the predicted changes in the aggregate cash ratio. These predictions assume that only opportunity costs changed. All other factors are held constant. We find that changes in opportunity costs can explain most of the secular variation in corporate cash holdings for the period 1945-2013 (Figures 5 and 6). The most notable exception is the period immediately following World War II and lasting until the late 1950s, during which firms held a large amount of government securities in relation to the war mobilization for reasons that were extraneous to the firms' usual economic motives for holding liquid assets. ${ }^{7}$ For example, U.S. firms received tax refunds in the form of war bonds (see Greenwood 2005). As a result, opportunity costs alone underpredict cash holdings at the very beginning of this period. We discuss the effect of financial innovation on other time periods during which the model's predictions slightly differ from observed cash holdings in the results section.

Next, to address endogenity concerns that may arise in the context of the time-series identification strategy, we identify the effect of opportunity costs on cash holdings in the cross-section. Using firm-level variation in the average ratio of non-interest bearing to total cash holdings (Compustat $\mathrm{CH}$ over $\mathrm{CHE}$ ) over time, we are able to replace the non-linear time trend of the time-series identification strategy with year-fixed effects. The cross-sectional coefficients are similar to those estimated in the time series. As robustness checks, we investigate the time stability of the estimated effect of opportunity costs on the cash ratio and find a statistically significant and largely stable effect of opportunity costs on cash holdings for all periods; ensure that similar results obtain for a balanced panel; and confirm that adding

\footnotetext{
${ }^{7}$ Based on the cash-to-asset series going back to 1920 reported in Graham, Leary, and Roberts (2013), we know that the abnormally high levels of the cash ratio indeed started during World War II. We also created a predicted series for the corporate cash ratio going back to 1920, and it closely matches the actual changes except for the world war period and its immediate aftermath. (Cash holdings increases from 1920 to 1950 while opportunity costs decreased from 1920 to 1950.) However, the data has not been made public yet.
} 
macro-variable such as GDP does not substantially change the results.

In sum, our results indicate that firms in the 1980s held less cash than today because the opportunity costs of doing so were higher in the 1980s. The economic intution is that the opportunity costs of cash, proxied by the nominal T-Bill, were high in 1980 while the portfolio of liquid assets returned only a fraction of its cost. As a result, firms economized cash holdings more in 1980 than in the years before or after.

We provide a second set of results that repeats the above analyses for the five largest European economies and Japan between 1996 and 2011. Because nominal interest rates change at different times across countries, and because the fraction of liquid assets held in non-interest bearing assets also varies across countries, we are able to include both yearand firm-fixed effects. Moreover, we find that the results from a regression using year fixed effects and those using a cubic time trend used in the U.S. specifications are similar. We show that differences in average opportunity costs explain differences in average cash ratios across countries very well, and it is also true that changes in opportunity costs over time can explain changes in the cash ratio over time within these countries. Notably, the regression coefficients in the cross-country study and for the within-country estimates match those obtained in the U.S.-only part of the paper. As a result, while Pinkowitz, Stulz, and Williamson (2013) argue that "the high cash holdings of U.S. firms before the crisis are a U.S.-specific puzzle", we find that once the effect of opportunity costs is taken into consideration, current U.S. cash holdings are not abnormal in the context of either a long-term or international perspective, or both. In particular, current U.S. cash holdings are quite similar to Japanese firm's cash holdings of recent years (Figure 7), and they are substantially lower than they were in 1950.

In sum, our results indicate that changes in the opportunity costs of holding cash have been a major driver of the observed changes in the cash holdings of U.S. firms. opportunity 
costs also have explanatory power for short-term movements in firms' cash ratios. Our paper does not show or even argue, however, that firm-level factors that affect the benefits of holding cash and that have previously been shown to drive firms' cash holdings are unimportant in resolving the corporate cash puzzle. We merely show that changes in opportunity costs alone can also explain much of the observed variation. We note, however, that our explanation can also predict the historical pattern of cash holdings over a much longer period than the previous literature has attempted to explain. Explaining the international variation with some of the existing approaches may also prove more difficult.

The paper proceeds as follows. Section 2 relates the paper to the existing corporate finance literature on corporate cash holdings. Section 3 lays out theoretical considerations investigating why firms demand liquid assets despite positive opportunity costs of doing so, and why these opportunity costs change over time. Section 4 details the data sources and empirical specifications. Section 5 presents the results for the U.S., and section 6 gives the international results. Section 7 concludes.

\section{Corporate Finance Literature}

The present paper is related to three literatures. The first one is the large and growing literature on the dynamics of U.S. corporate cash holdings. The second one is a smaller literature on international differences in cash holdings and their determinants. The third one is the small but growing literature linking macroeconomics to corporate finance.

The existing literature on the U.S. corporate cash-holdings puzzle has focused on two sets of determinants of firms' liquidity demand. The first strand builds on the idea that firms

hoard cash due to precautionary motives. It explains the increase in cash over the last 30 
years with changing firm characteristics and changes in the composition of firms. A prominent example is Bates, Kahle, and Stulz (2009), who approach the question "Why do US firms hold so much more cash than they used to?" by documenting that firm-level variables such as cash-flow volatility, $R \& D$, market-to-book ratio, and leverage have statistically significant correlations with the cash-to-assets ratio. They also decompose changes in the characteristics of firms and changes in the composition of firms in the sample. Duchin (2010) shows that firms' increased focus can be a driver of the precautionary motive for holding cash over time. A variation of the argument, by Falato, Kadyrzhanova, and Sim (2013), focuses on the increasingly important role of firms' intangible capital, which can explain the increased benefits of holding cash. Many more explanations have been proposed in the recent past, evidencing the strong interest by researchers in resolving the puzzle. ${ }^{8}$

The second strand focuses on the role of repatriation taxes. Foley, Hartzell, Titman, and Twite (2007) show that multinational firms hold more cash, which suggests repatriation taxes are an important motive for holding cash. Pinkowitz, Stulz, and Williamson (2012) show that firms do not increase their cash holdings after becoming multinational.

All of these papers propose explanations for the increase of cash holdings in the last thirty years that are based on increased benefits of holding cash. None of them considers changes in the opportunity costs of holding cash as a potential siginificant driver of corporate cash holdings. The only paper that focuses on a factor that affects opportunity costs is Stone, Gup, and Lee (2013), who explore whether interest rates have an effect on firm-level demand

\footnotetext{
${ }^{8}$ Pinkowitz, Stulz, and Williamson (2013) focus on abnormal cash holdings of U.S. firms in the recent past. Gao (2013) proposes the widespread adoption of just-in-time inventory management as a key explanation for the increase in cash holdings of manufacturing firms. Consistent with her empirical finding that cash and inventory are substitutes, we find that opportunity costs have power to predict U.S. inventory dynamics over the last several decades. Less motivated by time-series than by cross-sectional variation, Dittmar and MahrtSmith, 2007 investigate how the value of a marginal dollar of cash depends on the quality of governance. Della Seta (2011) and Morellec, Nikolov, and Zucchi (2009) show that competition increases cash holdings.
} 
for cash. They find an unstable negative correlation between interest rates and cash holdings beginning in 1970 that disappears in the 1990s. In contrast to their paper, we do acknowledge the distinction between nominal rates and opportunity costs that arises because the return to the corporate cash portfolio is non-zero - physical cash earns zero return, but "cash" invested in the T-Bill earns the nominal rate. Furthermore, we assess whether opportunity costs have the power to explain the secular trends in corporate cash holdings. The sample we consider is much longer, and we speak to cross-country differences in cash holdings, as well as the time-series variation in cash holdings in these countries. Lastly, our regressions have firm-fixed effects and year-fixed effects, which addresses a variety of endogenity concerns that might otherwise be present.

Azar and Kagy (2011) are the first to apply the insights from the macroeconomic literature on money demand to the corporate cash puzzle. ${ }^{9}$ Using aggregate data on corporate cash holdings from Fed flow of funds, they estimate the money demand of the nonfinancial corporate sector using a vector autoregression (VAR) analysis. They find that shocks to opportunity costs can explain around $80 \%$ of the long-run variations in aggregate corporate cash holdings and around $50 \%$ of the medium-run variations. Their findings show that in the context of a VAR model of aggregated data for the corporate sector, shocks to opportunity costs can explain most of the increase in corporate cash holdings between 1980 and 2010, whereas corporate cash holdings do not have a significant effect on opportunity costs. Unlike Azar and Kagy (2011), the present paper uses Compustat data and estimates the sensitivity of firm-level cash holdings to opportunity costs and controls for firm characteristics. The

\footnotetext{
${ }^{9}$ The estimation of changes in money demand as a function of the opportunity costs of holding money constitutes a large literature in macroeconomics. Meltzer (1963) was one of the first papers to find an effect of interest rates on money demand. For more recent estimates of the effect of the opportunity costs of holding money on money demand at the level of the whole economy, see Lucas (1988), Stock and Watson (1993), Ball (2001), and Teles and Zhou (2005). The firm-level estimates presented in this paper are comparable to the estimates from the macroeconomics literature.
} 
latter allows us to control for potential changes in the marginal benefit of holding cash over time. In addition, we show that the relationship between cash holdings and opportunity costs holds across industries and for various types of firms, which is only possible using firm-level data.

The literature on international evidence has focused on agency problems, and how differences in governance affect the value of cash (Dittmar, Mahrt-Smith, and Servaes, 2003; Pinkowitz, Stulz, and Williamson, 2006; Kalcheva and Lins, 2007). The evidence is largely consistent with US evidence such as that presented in Harford, Mansi, and Maxwell (2012). Somewhat differently from the previous papers, Lins, Servaes, and Tufano (2010) examine firms' choice between cash and lines of credit in an international context, and Agca (2012) investigates the effect of financial integration on corporate cash holdings in a cross-country study. We are not aware of previous papers linking monetary policy to cash holdings across countries.

By considering a macro-variable as an explanation for firm-level corporate finance policies, we contribute to an increasing literature at the interaction of macroeconomics and corporate finance (e.g. Dittmar and Dittmar (2002, 2008); Muir and Eisfeldt (2013)).

\section{Theory: Demand for Liquid Assets}

The section following this constructs a measure of opportunity costs that takes the composition of firms' liquid asset portfolio as given. In this section, we provide theoretical considerations to make sense of the observed variation in that composition. These considerations also help understand why these opportunity costs change over time. Before arriving there, we discuss why firms demand liquid assets, and how this is related to the present research 
in relation to existing approaches.

Our starting point is the simple model in Figure 1, based on Opler, Pinkowitz, Stulz, and Williamson (1999). Being short of liquid assets is costly for a firm. Holding liquid assets decreases the probability that a firm will be short of cash. The marginal benefit of holding an additional dollar of cash is the reduction of the probability that the firm will be short of cash. As in Opler, Pinkowitz, Stulz, and Williamson (1999), we assume that the marginal benefit of an additional unit of liquid assets declines as holdings of liquid assets increase, creating a downward-sloping demand curve for liquid assets. In contrast, the marginal cost of holding an additional unit of liquid assets is equal to the spread between the return on an alternative investment with the same risk characteristics minus the return on the firm's liquid assets portfolio. ${ }^{10}$ Cash is a risk-free investment. Thus, the gross cost of holding cash should correspond to the risk-free rate. Empirically, we approximate the risk-free rate with the threemonth T-Bill rate. The return on the cash portfolio is typically lower than the T-Bill because a substantial fraction of cash is held in non-interest bearing currency and checking accounts. We will assume that such non-interest bearing assets earn a zero nominal return, while interest-bearing short-term investments earn the nominal T-Bill return. Denoting the share of non-interest bearing forms of cash investments of firm $i$ at time $t$ as $s_{i, t}$, the opportunity cost of holding one dollar of cash of firm $i$ at time $t$ is

$$
O C_{i, t}=\mathrm{T}-\mathrm{Bill}_{t}-\left(1-s_{i, t}\right) \cdot \mathrm{T}-\mathrm{Bill}_{t}=s_{i, t} \cdot \mathrm{T}-\mathrm{Bill}_{t}
$$

In all existing papers we are aware of, this marginal cost is assumed to be roughly constant

\footnotetext{
${ }^{10}$ Note that the alternative investment of cash with the same risk characteristics is "not holding cash," i.e. paying down debt or disbursing cash to equity holders. The alternative project is not "investing in real assets," which has different risk characteristics and therefore a different cost of capital. We assume that the firm invests in all real NPV-positive projects. The decision we consider is what the firm does with any remaining cash after such investments.
} 
over time, whereas we allow it to vary. The measure outlined above makes clear that there are two reasons why opportunity costs fluctuate over time. One is that the nominal T-Bill rate fluctuates. The other is that the ratio of non-interest bearing to interest bearing assets in the liquid asset portfolio fluctuates. The part that may need additional evidence and explanation is why there is substantial variation over time in the way corporations invest their cash.

Fed flow of funds data on the composition of corporate liquid asset holdings, presented in Figure 3(a), show that firms hold many types of liquid assets, ranging from currency (i.e. physical cash reserves) to money market mutual funds. These assets provide varying degrees of liquidity benefits and pay different rates of return. Figure 3(b) aggregates all non-interest bearing liquid assets and all interest-bearing liquid assets in one group each and shows the declining time-trend of the fraction of non-interest bearing liquid assets as a share of total assets over time. We propose a simple theory in which firms balance the different liquidity benefits and the different returns of various liquid assets, and thus choose to hold more than one type of liquid asset.

We assume that firms have two types of cash-flow shocks. Under the first type of shock, they need the cash immediately (e.g., the need to make everyday transactions). Under the second type of shock, firms need the cash in the near future, but not immediately (e.g., to invest in new projects). As explained below, firms hold assets with varying degrees of liquidity because of frictions in the capital market that lead to a delay or a cost in converting some of the assets to cash.

We divide the liquid assets that firms can hold into two broad asset categories. Type-1 liquid assets can address liquidity shocks of both types 1 and 2; that is, they can be used for everyday transactions. In contrast, Type-2 liquid assets can address liquidity shocks of type 2 
only; that is, they cannot be used for everyday transactions. Whereas Type- 1 assets provide a greater liquidity benefit, the return to holding them is lower (possibly a zero nominal return). We assume that currency and checking accounts are the only Type-1 assets. Savings and time deposits, mutual funds, and other liquid assets allow for less than instantaneous liquidity, and thus can be used to address only type 2 shocks.

Because currency and checking accounts provide more liquidity than other assets, but at the cost of lower returns, firms will hold a mix of both categories of assets. Their relative holding of each category depends on how long it takes to convert holdings in mutual funds to checking accounts, and the cost of doing so. The time and cost of such conversion have gone down over time, due to improvements in electronic-payments technology. As a result, today firms hold a relatively small fraction (around 20\%) of their liquid assets in currency and checking accounts. The fraction of liquid assets held in currency and checking accounts was much higher in the 1970s, at around $60 \%$ of the corporate portfolio of liquid assets (we discuss the evolution of the components of the corporate portfolio of liquid assets in detail in the next section).

The fact that a portion of the liquid assets portfolio is held in assets that pay a lower nominal rate than the nominal interest rate creates a spread between the nominal interest rate and the rate of return on the portfolio of liquid assets held by the corporate sector (Figure 4). The spread has fallen over the last three decades for two reasons. First, the nominal interest rate decreased from around 15\% in 1980 to almost zero today, leaving little room between the nominal interest rate and the zero lower bound on the nominal return to cash. Second, improvements in electronic-payments technology led firms to hold a much higher fraction of their liquid portfolios in interest-bearing assets, thus reducing the wedge 
between the nominal interest rate and the rate of return on their liquid assets portfolio. ${ }^{11}$

A second reason for a cost of holding cash comes from a difference between the corporate and personal income tax rates (Graham, 2000; Faulkender and Wang, 2006). If the corporate tax rate is $35 \%$ and personal income is taxed at $10 \%$, the after-tax return on a cash portfolio invested at $18 \%$ (the Fed funds rate in 1980) is $11.7 \%$ if invested by the corporation and $16.2 \%$ if invested by the individual. If the cash is invested at a rate close to $0 \%$ (realistic in the current interest rate environment), the tax disadvantage is minimal. In principle, the tax motive would therefore also lead to the cost of holding cash being positive correlated with interest rates. However, the wedge between personal and corporate income taxes was much smaller in the 1980s than it is now, and therefore much smaller than the above example suggests. Now that the wedge is considerable, nominal rates are close to zero, so that the difference in tax payments is hardly relevant. Before 1980, personal marginal tax rates were higher than the corporate tax rate, rendering the tax motive unsuitable for explaining the cost of holding cash for the time before 1980. Even if the wedge had been the same since 1945, because the tax mechanism applies only to the $50 \%$ of cash holdings that were not invested in currency and checking accounts in 1980 and is less important in the current interest rate environment, differences in the return on the corporate cash portfolio are the first-order driver of changes in opportunity costs over the last decades. Therefore, when constructing our measure of opportunity costs, we rely only on the share of assets invested in the different asset classes and do not examine the tax explanation.

Whether changes in opportunity costs can quantiatively explain the increase in cash holdings since the 1980s is an empirical question. The answer depends on the magnitude of

\footnotetext{
${ }^{11}$ In any standard risk management model in the style of Bolton, Chen, and Wang (2011), optimal cash holdings correlate negatively with the cost of holding cash; see also Bolton, Schaller, and Wang (2013) and Tobin (1956). Modern papers on the subject are typically agnostic about the source of this cost of cash, however.
} 
the decline in opportunity costs during that period, and the slope of the demand curve in Figure 1. In the next section, we show that the changes in opportunity costs and the slope of the demand curve with respect to opportunity costs are in fact large enough to resolve the cash puzzle.

\section{Data and Empirical Method}

\subsection{Data}

Following the existing literature, we calculate firm-level cash-to-assets ratio of all CRSP/ Compustat firms in the years 1951-2011 as cash and short-term investments divided by total assets. We also calculate the aggregate cash-to-assets ratio for the nonfinancial corporate sector using Fed flow of funds data from 1945 to 2013 as the sum of currency and checking deposits, time and savings deposits, money market mutual fund accounts, government securities, and mutual fund shares, divided by the book value of total assets.

While Compustat data are needed for firm-level regressions, Fed flow of funds data give an arguably cleaner picture of the dynamics of corporate cash holdings, for several reasons. (i) Fed flow of funds data are consolidated for the sector; (ii) the Compustat sample includes only firms with publicly traded securities, whereas the Fed flow of funds data include the cash holdings of all privately owned firms; (iii) the Compustat sample is missing many firms, especially in the pre-1980 period; and (iv) Compustat data start in 1951, whereas we can calculate the cash-to-assets ratio from flow of funds data starting in 1945 . Because of the arguably greater accuracy, we build our first set of results on Fed Flow of Funds data alone, and afterwards show that very similar results obtain using Compustat data. The two measures of the cash ratio show a similar pattern over time: both decrease between 
1945/1951 and around 1980, and then increase between 1980 and 2011. To be more precise, the Fed flow of funds cash ratio reaches its minimum in 1982, shortly after interest rates peak. The Compustat cash ratio starts its secular increase a few years later. (The literature on the "corporate cash puzzle" is largely based on the final 30 years of that time series.) Our econometric approach works well for both measures. Figure 2 shows the cash ratio calculated using the Fed flow of funds data between 1945 and 2013. The figure also shows the opportunity costs measure, whose construction we now describe.

We calculate the opportunity costs of holding liquid assets as the spread between the three-month T-Bill rate and the rate of return on the portfolio of liquid assets held by the corporate sector. To estimate the cost of holding cash inside the firm, we need to find the cost of the "project" of holding cash. Given that cash, whether held as currency or in an interest-bearing risk-free asset, is a risk-free project, its cost of capital is equal to the risk-free rate. As a proxy, we use the T-Bill from FRED. As Nagel (2014) points out, the T-Bill also contains a liquidity premium, which makes it an imperfect, but still very good proxy for the opportunity costs of holding cash. The secular fluctuations in the T-Bill rate eclipse the liquidity premium. Moreover, the liquidity premium positively comoves with the nominal rate. As a result the cost of cash was lower then the T-Bill rate in 1980 when the liquidity premium was high, making cash holdings relatively less expensive than what the T-Bill rate indicates. Thus, our results are biased against the hypothesis we advance, and risk considerations are unlikely to be a contributor to our findings.

To approximate the return on the liquid assets portfolio of the nonfinancial corporate sector, we use Fed flow of funds data on the composition of liquid assets for the sector to calculate a rolling 20-year average of the share of liquid assets held in currency and checking accounts. By using a 20-year moving average, we get less variation than we would by 
using the contemporaneous composition of cash holdings, but alleviate endogeneity concerns regarding the composition of the liquid assets portfolio. ${ }^{12}$ Figure 3(a) shows the components of the cash portfolio for the nonfinancial corporate sector between 1945 and 2013. ${ }^{13}$ The composition of the liquid assets portfolio changed dramatically throughout the period. In 1945, the nonfinancial corporate sector held essentially only two categories of liquid assets: currency and checking deposits, and government securities. Between 1945 and around 1980, we see a large reduction in the fraction of government securities, and an increase in time and savings deposits. Between 1980 and the present, the corporate sector reduced the fraction of the liquid assets portfolio held in currency and checking accounts, and added mutual funds to its portfolio (both money market and other types of mutual funds). Figure 3(b) shows the fraction of the liquid assets portfolio held in currency and checking accounts between 1945 and 2013, together with its 20-year moving average. The nonfinancial corporate sector's share of liquid assets held in currency and checking accounts was relatively stable around

\footnotetext{
${ }^{12}$ Data on firm-level variation in the composition of cash become available only after 2009 (Duchin, Gilbert, Harford, and Hrdlicka, 2013) - for similar endogeneity reasons, however, one would not want to use them for the construction of the returns to cash, even if they were available throughout the sample period.

${ }^{13}$ We think of the long-run changes in the portfolio of liquid assets as an endogenous decision made by firms that is driven by changes in financial regulation and technology. Such changes in financial regulation and technology are not driven by the firms' short-term liquid portfolio choice. These changes gave rise, for example, to the emergence of money market mutual funds (see Teles and Zhou, 2005). Due in part to the rapid development of electronic payments in the 1990s, nowadays firms can easily hold mutual fund shares and other interest-bearing liquid assets, thus decreasing the opportunity costs of holding cash. The liquidity provided by interest-bearing assets was lower in 1980 than it is today, thus justifying the decrease in currency and checking accounts as a share of total liquid assets. Also, Regulation Q, which imposed maximum rates of interest on savings accounts and other bank deposits, made it much less attractive relative to firms until 1986 to hold money in what we would now consider interest-bearing accounts, relative to holding cash in currency. The repeal of Regulation Q, driven by firms' demand for interest bearing assets in a highly inflationary enviroment, relieved such constraints and made it possible for firms to substitute non-interest bearing cash holdings with interest-bearing alternatives. The repeal, however, is not suitable as an instrument, because (i) its phase-out was gradual 1981-1986 and market participants had already found loopholes around interest rate restrictions before its official phasing out, and (ii) because the repeal itself ocurred in response to the existing loopholes, i.e. the causality goes two ways. Similarly, the introduction of SWEEP accounts in the mid-1990s comes contemporaneously with the widespread acceptance of money-market mutual funds and other interest-bearing liquid assets and is therefore not ideally suitable as an instrument.
} 
$60 \%$ until the 1970s, when the share began to fall steadily until the present, to around $20 \%$ of the liquid assets portfolio.

For the construction of the return on cash measure, we assume the currency and checking component of the liquid assets portfolio has a zero nominal return. We proxy for the return on all other components using the nominal three-month T-Bill rate (historical data on rates for money market accounts only go back to 2000 in FRED; historical data on certificates of deposit go back to 1964). Figure 4 shows the three-month T-Bill rate together with the return on the nonfinancial corporate sector's portfolio of liquid assets. Note that substantial comovement occurs between the the level of interest rates and the cost of holding cash (the difference between the blue and red lines in Figure 4 - this difference is depicted as the opportunity costs of cash (red dotted line) in Figure 2.) Note also that in recent years, the return on the liquid assets portfolio has been much closer to the T-Bill rate than in the past, due to the higher share of the portfolio held in interest-bearing assets.

From the Compustat database, we calculate a set of firm-level control variables: firm size, industry cash-flow volatility, cash flow, net working capital, a dividend dummy, and R\&D expenditures. Table 1 shows summary statistics for these control variables. Variable definitions are provided in the Appendix.

\subsection{Static Regressions}

Figure 2 suggests a strong negative correlation between the cash ratio and the opportunity costs of holding cash between 1945 and 2013. We now adopt a quantitative approach to make the claim that the latter has the power to explain the former. We estimate the response of the corporate cash ratio to changes in the opportunity costs of holding cash, while controlling for factors that change the marginal benefit of holding cash. We thus test the hypothesis 
that opportunity costs affect cash holdings against the null hypothesis that they don't. In particular, we run regressions of the log cash ratio as a function of opportunity costs, a cubic time trend, firm fixed effects, as well as firm-level control variables. ${ }^{14}$ These specifications are analogous to the basic models of money demand analyzed in the macro literature; however, they are estimated at the firm level and introduce controls for firm-level characteristics:

$$
\log \left(\frac{\text { Cash }_{i t}}{\text { NetAssets }_{i t}}\right)=\beta \cdot O C_{t}+\gamma \cdot X_{i t}+f(t)+\nu_{i}+\varepsilon_{i t},
$$

where $O C_{t}$ is the opportunity costs of holding cash at time $t$, and $X_{i t}$ is a vector of firmlevel controls. Because we control for a time trend $f(t)$, we are identifying the effect of opportunity costs on the cash ratio from variation of cash ratios and opportunity costs around their trend. In the reported results, we use a cubic time trend. The results, however, are robust to other non-linear forms; we tried up to order 5. The changes in opportunity costs are driven by macroeconomic factors, and are therefore likely to be exogenous at the level of the individual firm. We run additional regressions including real GDP to control for the potential effect of the business cycle on cash holdings, and find similar results (reported in appendix tables B.1 and B.2). ${ }^{15}$

The first specification includes only firm size as a firm-level control. Following Bates, Kahle, and Stulz (2009), the second specification is similar to the first, except that it uses the raw cash-to-assets ratio instead of the logarithm of the cash ratio as a dependent variable:

$$
\frac{\text { Cash }_{i t}}{\text { Assets }_{i t}}=\beta \cdot O C_{t}+\gamma \cdot X_{i t}+f(t)+\nu_{i}+\varepsilon_{i t} .
$$

\footnotetext{
${ }^{14}$ Following Petersen (2009), we cluster standard errors by both firm and year unless otherwise noted.

${ }^{15}$ We find that the log of real GDP has a significant effect on firms' cash ratios in static specifications, but the effect of GDP on cash ratios is not significant when controlling for lagged values of the cash ratio. In either case, the coefficient $\beta$ on the opportunity costs is not strongly affected.
} 
Specifications 3 and 4 are similar to specifications 1 and 2, except that they include the full set of firm-level controls.

One problem with the Compustat panel-especially in the early years of the sample-is that some control variables are missing for many of the firms. To avoid losing these observations, the ability to impute (or "fill in") the missing data with plausible values would be desirable. A naive imputation method, however, may create more problems than it would solve. Simple imputation methods, for example, overstate the precision of estimates because they do not account for the uncertainty regarding the imputed values. Multiple imputation is a statististically valid method of imputing data. ${ }^{16}$ Specifications 5 and 6 are similar to specifications 3 and 4, except that their estimation uses multiple imputation to avoid dropping observations with some missing controls. ${ }^{17}$

In all specifications, we weight firms by their average assets over time, multiplied by the number of time periods in which the firm is in the sample. The motivation for this weighting scheme is that the aggregate cash ratio in the Fed flow of funds data can be thought of as an asset-weighted average of firm-level cash ratios. The main results do not change if we estimate the specifications using simple OLS instead of WLS. Using a balanced panel of firms between 1980 and 2011 also leads to a similar estimated effect of opportunity costs on cash-to-assets ratios.

\footnotetext{
${ }^{16}$ Rubin (1987) developed a multiple imputation procedure that allows statistically valid imputation of missing values. Multiple imputation of missing values allows us to incorporate observations that are missing some controls in our analysis of the effect of opportunity costs on the cash ratio, while modeling the uncertainty associated with the missing observations. Following Schafer (1999), we impute missing values for net working capital, cash flow, industry sigma, leverage, acquisitions, capital expenditures, and the marketto-book ratio, based on all the other variables in each regression specification. Fields other than corporate finance are already applying the multiple-imputation procedure on a large scale: labor economics (Brownstone and Valletta, 1996), health economics (Shore-Sheppard, Buchmueller, and Jensen, 2000), political science (King, Honaker, Joseph, and Scheve, 2001), transportation economics (Steimetz and Brownstone, 2005), and medical research (see Mackinnon, 2010 for a review).

${ }^{17}$ We cluster by firm in the specifications that use multiple imputation.
} 


\subsection{Dynamic Regressions}

We also run dynamic regressors with the lagged cash ratio as a regressor ${ }^{18}$ :

$$
\log \left(\frac{\text { Cash }_{i t}}{\text { NetAsset }_{i t}}\right)=\alpha \log \left(\frac{\text { Cash }_{i, t-1}}{\text { NetAssets }_{i, t-1}}\right)+\beta \cdot O C_{t}+\gamma \cdot X_{i t}+f(t)+\nu_{i}+\varepsilon_{i t} .
$$

Similar to the levels regressions, the first dynamic specification includes only firm size as a firm-level control. As before, the second dynamic specification is similar to the first, except that it uses the raw cash-to-assets ratio as a dependent variable instead of the logarithm of the cash ratio:

$$
\frac{\operatorname{Cash}_{i t}}{\operatorname{Assets}_{i t}}=\alpha \frac{\operatorname{Cash}_{i, t-1}}{\operatorname{Assets}_{i, t-1}}+\beta \cdot O C_{t}+\gamma \cdot X_{i t}+f(t)+\nu_{i}+\varepsilon_{i t} .
$$

The dynamic specifications 3 and 4 are similar to specifications 1 and 2, except that they include the full set of firm-level controls. The dynamic specifications 5 and 6 are similar to specifications 3 and 4, except that their estimation uses multiple imputation to avoid dropping observations with missing controls.

\subsection{Cross-sectional Identification}

In our main results, we identify the effect of opportunity costs on corporate cash holdings from the variation of opportunity costs over time around a cubic time trend, using aggregate Fed Flow of Funds data to construct the opportunity costs of holding cash. The effect can also be identified in the cross section, using firm-level variation in the share of interest

\footnotetext{
${ }^{18}$ We note that running a regression in levels controlling for lagged values of the dependent variable is arithmetically equivalent to running a regression in differences controlling for lagged values of the dependent variable.
} 
bearing versus not interest bearing cash investments, and controlling for year fixed effects. We construct a firm-level measure of opportunity costs using Compustat data on the fraction of cash that is held in immediately negotiable media of exchange (variable $\mathrm{CH}$ ) compared to the fraction held in interest bearing assets (variable $C H E$ ). Most of the components included in immediately negotiable media of exchange pay zero or low interest, and thus we use this as a proxy for the fraction of liquid assets that is non-interest-bearing. Most of the assets in $C H E$ pay a rate of return close to the T-Bill rate. (The composition of both is listed in the appendix.) We then construct a measure of firm-level opportunity costs by multiplying the fraction of cash held in immediately negotiable media of exchange by the three-month T-Bill rate. This is equivalent to subtracting the return on the cash portfolio from the cost of holding cash, which we assume to approximate the T-Bill rate as before. Because this measure of opportunity cost varies in the cross section in addition to over time, we can include both firm and year fixed effects. Our main specification is the following:

$$
\log \left(\frac{\text { Cash }_{i t}}{\text { NetAssets }_{i t}}\right)=\beta \cdot O C_{i t}+\gamma \cdot X_{i t}+\gamma_{t}+\nu_{i}+\varepsilon_{i t} .
$$

A potential concern is that the fraction of cash held in interest-bearing assets by the firm is endogenous due to division bias, and potentially for other reasons due to the fact that the composition of liquid assets is a choice variable for the firm. We address this endogeneity concern by running two additional specifications. In the first additional specification, we average the fraction of cash held in interest-bearing assets by industry, creating an industrylevel measure of opportunity costs. In the second additional specification, we instrument firm-level opportunity costs using the T-Bill rate times the firm's average level for the whole time period of the fraction of cash that is held in immediately negotiable media of exchange. That is, we create an instrumental variable $O C_{i t}^{I V}=\overline{\left(\frac{C H}{C H E}\right)_{i}} R_{t}$, where $R_{t}$ is the T-Bill rate. 
We are identifying the effect out of the difference in the response to interest rates of firms that hold most of their cash in interest bearing assets on average over time and firms that hold most of their cash in non-interest bearing assets on average over time. This identification strategy greatly attenuates the problem of division bias, since any measurement error in $\mathrm{CH} / \mathrm{CHE}$ will be averaged over time. Our identification assumption is that the error does not contain an unobserved factor that affects the sensitivity of a firm's cash holdings to interest rates, and that is also correlated with the share of cash that is held in interestbearing assets.

\section{Results on the U.S. Cash Puzzle}

\subsection{Effect of Opportunity Costs on Corporate Cash Holdings}

Table 2 shows the results from the static regressions of firm-level money demand. The regressions with the logarithm of the net cash ratio as the dependent variable yield a range of estimated effects of opportunity costs on corporate money demand between -13 and -20. In the specifications with the cash ratio in levels, we find estimated effects between -.6 and -1.1, indicating robustness to a different functional form. ${ }^{19}$ These coefficients are not only highly statistically significant, but also large enough to explain the more-than-doubling of corporate cash holdings in the last 30 years. In particular, a coefficient of -14 means that if opportunity costs decrease by -1 percentage point, cash holdings increase by approximately $15 \%$. The regression results for the dynamic specifications are shown in Table 3. The coefficients are

\footnotetext{
${ }^{19}$ We find no significant effect of industry sigma on firms' cash ratios, which is at odds with some results reported in the literature. This difference is driven by the fact that we are weighting by firm size and number of periods with observations, and is not driven by the fact that we are including opportunity costs. If we use OLS instead of WLS, we find that industry sigma has a significant effect on firms' cash ratios. As mentioned previously, changing the weights does not change our main results.
} 
comparable in magnitude and also highly statistically significant throughout. The next set of results provides more analyses to gauge the economic magnitude of the results.

\subsection{Implications of Estimated Effects for the Corporate Cash Puz- zle}

To see if the observed changes in opportunity costs can resolve the corporate cash puzzle in the sense of predicting a substantial share of the time-series variation, we calculate the predicted response of corporate cash holdings to variations in opportunity costs, holding all factors other than opportunity costs constant. The static calculations use the estimated effect from specification 5 in Table 2 .

Figure 5(a) compares the predicted values of the cash ratio with the actual cash ratio between 1945 and 2013 from Fed flow of funds. ${ }^{20}$ We normalize the predicted series so that its average value in logs is equal to the average value for the actual series. We can see from the graph that changes in opportunity costs over the period can explain most of the longrun changes in the corporate cash-to-assets ratio. The only exception is that from the end of World War II until the end of the 1950s, actual corporate cash holdings were higher than the predicted values. A likely reason is that our econometric model does not account for the fact that personal income taxes relative to corporate income taxes were much higher then than they are today, giving firms an additional incentive to hold on to more cash and not pay it out. ${ }^{21}$

\footnotetext{
${ }^{20}$ Because government securities are a small component of the liquid assets portfolio during most of the sample period except during the 1950s as a consequence of government incentives associated with World War II, we exclude them from the calculation of the cash ratio. During World War II and in its aftermath, for reasons unrelated to transaction or precautionary motives, the corporate sector held a large number of government securities related to the war mobilization (see, e.g., Greenwood, 2005).

${ }^{21}$ As the dynamics of tax rates does not seem to have the potential to explain the secular trends over long horizons, we do not include this variation in our econometric approach. We want to make clear that the sole
} 
For Figure 5(b), we calculate predicted values starting with the cash ratio in 1945 and applying the estimated dynamic model. We calibrate the constant so that the mean log cash ratio implied by the dynamic model (given the average level of opportunity costs) is equal to the mean log cash ratio in the data. The results from this prediction exercise, consistent with the approach used in the static predictions, use the estimates from specification 5 in Table 3. The predicted level of cash quite closely matches the observed levels, however, the model slightly overpredicts the increase in corporate cash holdings from 1980-2013. The increasing availability of credit lines, which can serve as a substitute of internal cash holdings, may explain that firms increased their observable liquidity reserves less than changes in the opportunity costs of cash would predict.

Figure 6 shows the results of a static prediction exercise identical to that in Figure 5(a), but using quarterly data instead of yearly, and focusing on the period 1980-2013. We can see from the graph that changes in opportunity costs over the period can explain some of the short-run changes in the corporate cash-to-assets ratio, whereby our predictions anticipate the actual changes slightly. (We use annual data in the other specifications to be consistent with the bulk of the existing literature. $)^{22}$

driver of the results presented in this paper are opportunity costs.

${ }^{22}$ The slight overprediction in the early 1990s and to a lesser extent the early 2000s may be due to the introduction of SWEEP accounts in the mid-1990s, which made it cheaper for firms to hold a given amount of cash, as they can hold a higher fraction of it in interest-bearing accounst while allowing similar benefits in terms of liquidity management. As our opportunity cost measure is based on a 20-year moving average ratio of cash held in interest-bearing and non-interest bearing accounts, our econometric model would then assume too high a fraction in interest-bearing accounts before and after the introduction of SWEEP accounts, and thus overpredict the amount of cash firms "should" have held, given interest rates. 


\subsection{Effect of Opportunity Costs on Cash Holdings for Different Types of Firms}

To examine cross-sectional robustness of the effect of opportunity costs on the cash ratio, we re-estimate our baseline specification (specification 5 in Table 2) for various firm types. In particular, for each firm-level control, we calculate the average for each firm. We then divide firms into two groups according to whether their time averages of the control variable are above or below the median time average. In general, we are not aware of theories predicting a different sensitivity of cash holdings to opportunity costs for different firm characteristics. However, it is possible that firms differ with respect to the slopes of their marginal benefit curve of holding cash.

The results are shown in Table 4 . We find that the estimated effect is generally similar across groups. Point estimates indicate that small firms' demand for cash is markedly less elastic than that of large firms, the effect for firms with high levels of R\&D is lower than for firms with low levels of $\mathrm{R} \& \mathrm{D}$, and that the effect for firms with high levels of acquisition activity is lower than for firms with low levels of acquisition activity. These differences, however, are not statistically significant. All groups have a significant estimated effect of opportunity costs on the cash ratio. Thus, the results largely confirm the validity of the hypothesis advanced in this paper for different subsets of firms.

Similarly, we run separate regressions for Manufacturing, Services, Retail Trade, and for "other" SIC industry divisions as a group. The results are shown in Table 5. The effect of opportunity costs is negative and statistically significant for all four groups of firms. The point estimate of the effect of opporutnity cost on the cash ratio is highest for Retail Trade. The reason is that retail trade firms hold significantly more cash in non-interest bearing liquid assets, which exposes them more to changes in nominal interest rates than other firms. While 
we generally take firms' liquid asset portfolios as given, we observe that it makes sense for Retail firms to hold more cash in currency because of the nature of their transactions with customers.

The above regressions are to be regarded as robustness checks only. They are meant to show that the results are not driven by a particular industry or set of firms. Whereas firm-

level cash levels of course show large cross-sectional variation that the literature understands quite well, we do not have a prior about cross-sectional variation in how firms' cash holdings should respond to changes in the cost of holding cash. Referring back to figures 1 and 3, we find such differences need to stem either from differences in the slope (not the level!) of the marginal benefit curve, or from systematic differences in the composition of the liquid assets portfolio across firm types. The opportunity costs of investing in the same portfolio of liquid assets should be the same for different firms, unless firms differ, for example, in the degree to which agency conflicts affect the value of cash in unobserved ways. In sum, absent clear theoretical predictions for cross-sectional variation (except for differences in the composition of the liquid asset portfolio, which we explore in the next subsection), we report the findings as saying that the effect of opportunity costs on cash holdings is robust across different types of firms and industries.

\subsection{Identification Using Cross-sectional Variation in the Oppor- tunity Costs of Holding Cash}

The results for the cross-sectional identification approach with firm-level variation in liquid asset holdings in interest bearing versus not interest bearing accounts are shown in Table 6. The first specification shows results using the industry-level measure of opportunity costs. The second specification uses the firm-level measure of opportunity costs, without 
instrumenting. The third specification uses the firm-level measure of opportunity costs, using

the IV strategy described in the methodology section. Specifications (4)-(6) are analogous to specifications (1)-(3), but controlling for lagged log of cash over net assets. In all cases, we find a statistically significant effect of opportunity costs on cash holdings, similar in magnitude to the estimates in the main specifications.

\subsection{Robustness Tests}

To examine the robustness of the estimated effect of opportunity costs on corporate cash demand over time, we perform rolling regressions of the static specification using the log of cash over net assets as the dependent variable, and opportunity costs, firm size, firm fixed effects, and a cubic time trend as controls. For each year in the rolling regression, the estimation window includes the 21-year period centered around the given year. Because we are using data going back to 1951 in the estimation of the rolling regressions, which is missing many of the control variables, we do not include the full set of firm-level controls in the rolling regressions. In Appendix Figure B.2, we present the time-series and confidence intervals of our estimates of the effect of opportunity costs on cash holdings. The effect is statistically significant for all time periods. The point estimates vary between approximately -6 and -19 , nesting the estimated effect in the main results section of -10 . The estimated effect decreases in absolute value from around -15 to around -6 during the first half of the 1960s, and then increases in absolute value until the present, to around -19.

Another concern is that Compustat data before 1970 suffers from a severe survivorship bias. We our regressions with a balanced panel of firms and find similar results. We omit reporting these results to conserve space. 


\section{International Evidence}

In this section, we use Compustat Global data to estimate the relationship between opportunity costs and firm-level cash ratios for the largest five European economies and Japan. For this purpose, we proxy for opportunity costs by using short-term nominal interest rates for each country, multiplied by the average by country and year of the fraction of cash that is held in immediately negotiable media of exchange. ${ }^{23}$ Because data are available for a small number of firms for earlier years, we use data for the period 1996-2011. ${ }^{24}$

Figure 7 shows a scatter plot of the time average of the cash ratio (defined as total cash divided by total assets) and the average opportunity costs for the period 1996-2011 for the United States, Japan, Germany, France, the United Kingdom, Italy, and Spain. We also show the cash ratio for the United States in 1980, 1990, 2000, and 2010. The regression line in the graph is estimated using the country averages, and not the points for the United States in 1980, 1990, 2000, and 2010. A negative relationship exists between average opportunity costs and the average cash ratio across countries. Japan's average cash ratio is high relative to other countries in the sample during the period 1996-2011. These high cash levels are explained by low opportunity costs during that period. The level of the cash ratio for the United States in 2010 is close to the value for Japan over the period 1996-2011, and the level of opportunity costs is also similar. The regression line has a slope of -1.14 - strikingly

\footnotetext{
${ }^{23}$ We use three-month treasury bill rates from the International Data section of Fred for Japan, France, the United Kingdom, Italy, Spain, and the United States. We use 90-day interbank rates for Germany because they are available for a longer time period. For the period during which three-month treasury bill rates are available for Germany, they are close to the 90-day interbank rates.

${ }^{24} \mathrm{Also}$, because of the shorter time period and the small number of firms for some countries, we cluster standard errors by firm only, as opposed to by firm and year as in the rest of the paper. This is following Petersen (2009): "When both a firm and a time effect are present in the data, researchers can address one parametrically (e.g., by including time dummies) and then estimate standard errors clustered on the other dimension. Alternatively, researchers can cluster on multiple dimensions. When there are a sufficient number of clusters in each dimension, standard errors clustered on multiple dimensions are unbiased and produce correctly sized confidence intervals whether the firm effect is permanent or temporary." (emphasis is ours).
} 
similar to the non-logged estimates obtained for the within-U.S.-analyses presented above. In sum, cash levels in U.S. firms have not been abnormal in any way in any period during the last 30 years, as judged by an international comparison.

Figure 8 shows the level of opportunity costs and the cash ratio by country over time for the period 1996-2011. The graphs indicate a negative correlation between cash-to-assets ratios and opportunity costs, similar to the U.S. evidence in Figure 2. Given a smaller amount of variation of opportunity costs over these short time periods, the relationships may not appear to be as stark, however.

Table 7 shows results of firm-level money demand regressions by country and of regressions including firms from all seven countries. The first seven specifications are estimated for each country separately and similar to specification 1 in Table 2 . The last two specifications show results pooling firms from all countries. Specification 7 uses a cubic time trend, and specification 8 controls for year fixed effects. We find a statistically significant negative effect of opportunity costs on the cash ratio for Germany, France, Spain, Japan, and the United States. For the UK and Italy, the estimated coefficient is negative but not significant; in the case of Italy, this lack of significance may be attributable to the small number of observations. We find a statistically significant negative coefficient in both pooled specifications, and the coefficients for the specification including a cubic time trend are similar to those in the specification including year fixed effects. ${ }^{25}$

Figure 9 shows the results of a prediction exercise for each country similar to that described previously for the United States in Figure 5. We use the estimated coefficient from the pooled specification with year fixed effects (Table 7, column 9). Even in these short samples with litte variation in opportunity costs, changes in opportunity costs over time can

\footnotetext{
${ }^{25}$ The U.S. coefficient is slightly lower than estimated in the U.S.-only part of the paper because of the different sample periods.
} 
explain some of the variation in cash ratios for France, Germany, and Spain. The variation in cash ratios over time for Italy, the United Kingdom, and Japan seems harder to rationalize as resulting from changes in opportunity costs. Note that the estimated effect of opportunity costs on cash ratios for Japanese firms is relatively large, but the changes in opportunity costs over time were small.

\section{Conclusion}

We provide evidence that changes in opportunity costs of holding cash can explain longrun changes in corporate cash holdings. We thus complement the large literature on the dynamics of corporate cash holdings that has thus far focused on changes in the benefits of holding cash. Our approach starts with the calculation of a measure of the opportunity costs of holding liquid assets. We then identify a large negative effect of opportunity costs on the cash-to-assets ratio of nonfinancial Compustat firms, using variation around the time trend of cash holdings from 1980 to 2011. We use that estimate to predict changes in aggregate cash holdings for 1945-2013 and find that they closely match actual changes in cash holdings over that period. Several robustness tests indicate that our results are applicable to a wide universe

of firms. Indeed, differences in opportunity costs also explain cross-country differences and within-country time variation of cash-to-assets ratios of firms in the five largest European economies and Japan. 


\section{References}

AGCA, S. (2012): "Financial Integration and Corporate Cash Holdings," Available at SSRN 2024097. 2

AzAR, J., AND J.-F. KAGY (2011): "Changes in the Opportunity Cost of Cash: A Solution to the Corporate Cash Hoarding Puzzle," Ph.D. thesis, Princeton University. 2

BALL, L. (2001): "Another look at long-run money demand," Journal of Monetary Economics, 47(1), 31-44. 9

Bates, T. W., K. M. Kahle, and R. M. Stulz (2009): "Why do US firms hold so much more cash than they used to?," The Journal of Finance, 64(5), 1985-2021. 2, 4.2, A.1

Bolton, P., H. Chen, and N. Wang (2011): "A Unified theory of Tobin's q, Corporate Investment, Financing, and Risk Management," The Journal of Finance, 66(5), 1545-1578. 11

Bolton, P., H. Schaller, and N. Wang (2013): "The Marginal Value of Cash and Corporate Savings," Discussion paper, Columbia University Working Paper. 11

Brownstone, D., and R. G. Valletta (1996): "Modeling earnings measurement error: a multiple imputation approach," The Review of Economics and Statistics, pp. 705-717. 16

Della Seta, M. (2011): "Cash and competition," Available at SSRN 1808979. 8

Dittmar, A., And R. DitTmar (2002): "Stock repurchase waves: An explanation of the trends in aggregate corporate payout policy," Available at SSRN 346548. 2 
Dittmar, A., And J. MAhrT-Smith (2007): "Corporate governance and the value of cash holdings," Journal of Financial Economics, 83(3), 599-634. 8

Dittmar, A., J. Mahrt-Smith, and H. Servaes (2003): "International corporate governance and corporate cash holdings," Journal of Financial and Quantitative analysis, $38(1), 111-134.2$

Dittmar, A. K., And R. F. Dittmar (2008): "The timing of financing decisions: An examination of the correlation in financing waves," Journal of Financial Economics, 90(1), 59-83. 2

Duchin, R. (2010): "Cash holdings and corporate diversification," The Journal of Finance, $65(3), 955-992.2$

Duchin, R., T. Gilbert, J. Harford, and C. M. Hrdlicka (2013): "Precautionary Savings with Risky Assets: When Cash Is Not Cash," Discussion paper, Available at SSRN: http://ssrn.com/abstract=2348415 or http://dx.doi.org/10.2139/ssrn.2348415. 12

Falato, A., D. Kadyrzhanova, And J. W. Sim (2013): "Rising Intangible Capital, Shrinking Debt Capacity, and the US Corporate Savings Glut," Discussion paper, Federal Reserve Board. 2

Faulkender, M., And R. WAng (2006): "Corporate financial policy and the value of cash," The Journal of Finance, 61(4), 1957-1990. 6, 3

Foley, C. F., J. C. Hartzell, S. Titman, and G. Twite (2007): "Why do firms hold so much cash? A tax-based explanation," Journal of Financial Economics, 86(3), 579-607. 2 
GaO, X. (2013): "Corporate Cash Hoarding: The Role of Just-in-Time Adoption," University of British Columbia. 8

Graham, J. R. (2000): "How big are the tax benefits of debt?" The Journal of Finance, 55(5), 1901-1941. 6, 3

Graham, J. R., M. T. Leary, and M. R. Roberts (2013): "A Century of Capital Structure: The Leveraging of Corporate America," Discussion paper, Working Paper. 5, 7

Greenwood, R. M. (2005): Aggregate corporate liquidity and stock returns. Division of Research, Harvard Business School. 1, 20

Harford, J., S. A. Mansi, And W. F. MaXwell (2012): "Corporate governance and firm cash holdings in the US," in Corporate Governance, pp. 107-138. Springer. 2

Kalcheva, I., AND K. V. Lins (2007): "International evidence on cash holdings and expected managerial agency problems," Review of Financial Studies, 20(4), 1087-1112. 2

King, G., J. Honaker, A. Joseph, and K. Scheve (2001): "Analyzing incomplete political science data: An alternative algorithm for multiple imputation," American Political Science Review, 95(1), 49-70. 16

Lins, K. V., H. Servaes, and P. Tufano (2010): "What drives corporate liquidity? An international survey of cash holdings and lines of credit," journal of financial economics, 98(1), 160-176. 2

LuCAS, R. E. (1988): "Money demand in the United States: A quantitative review," in Carnegie-Rochester Conference Series on Public Policy, vol. 29, pp. 137-167. NorthHolland. 9 
MaCKInNON, A. (2010): "The use and reporting of multiple imputation in medical researcha review," Journal of Internal Medicine, 268(6), 586-593. 16

Meltzer, A. H. (1963): "The demand for money: the evidence from the time series," The Journal of Political Economy, 71(3), 219-246. 9

Morellec, E., B. Nikolov, and F. Zucchi (2009): "Competition, Cash Holdings, and Financing Decisions," Available at SSRN 1364009. 8

Muir, T., And A. Eisfeldt (2013): “Aggregate Issuance and Savings Waves," Available at SSRN 1984063. 2

NAgel, S. (2014): "The Liquidity Premium for Near-Money Assets," Discussion paper, University of Michigan Working Paper. 4.1

Nikolov, B., And T. M. Whited (forthcoming): "Agency Conflicts and Cash: Estimates from a Structural Model," The Journal of Finance. 4

Opler, T., L. Pinkowitz, R. Stulz, and R. Williamson (1999): "The determinants and implications of corporate cash holdings," Journal of Financial Economics, 52(1), 3-46. 1,3

Petersen, M. A. (2009): "Estimating standard errors in finance panel data sets: Comparing approaches," Review of financial studies, 22(1), 435-480. 14, 24

Pinkowitz, L., R. Stulz, and R. Williamson (2006): "Does the contribution of corporate cash holdings and dividends to firm value depend on governance? A cross-country analysis," The Journal of Finance, 61(6), 2725-2751. 2 
Pinkowitz, L., R. M. Stulz, and R. Williamson (2012): "Multinationals and the high cash holdings puzzle," Discussion paper, National Bureau of Economic Research. 2

Pinkowitz, L., R. M. Stulz, and R. Williamson (2013): "Is there a U.S. High Cash Holdings Puzzle after the Financial Crisis?," Discussion paper, Fisher College of Business Working Paper No. 2013-03-07. Available at SSRN: http://ssrn.com/abstract=2253943. 1,8

Riddick, L. A., And T. M. Whited (2009): "The corporate propensity to save," The Journal of Finance, 64(4), 1729-1766. 4

RuBin, D. B. (1987): Multiple imputation for nonresponse in surveys. Wiley (New York). 16

Russolillo, S. (2013): "Carl Icahn's Letter to Apple CEO Tim Cook," Wall Street Journal. 2

SAnchez, J. M., And E. Yurdagul (2013): "Why are corporations holding so much cash?," Federal Reserve Bank of St. Louis' The Regional Economist, 21(1), 5-8. 1

Schafer, J. L. (1999): "Multiple imputation: a primer," Statistical methods in medical research, 8(1), 3-15. 16

Shore-Sheppard, L., T. C. Buchmueller, and G. A. Jensen (2000): "Medicaid and crowding out of private insurance: a re-examination using firm level data," Journal of Health Economics, 19(1), 61-91. 16

Steimetz, S. S., And D. Brownstone (2005): "Estimating commuters' "value of time" 
with noisy data: a multiple imputation approach," Transportation Research Part B: Methodological, 39(10), 865-889. 16

Stock, J. H., And M. W. Watson (1993): "A simple estimator of cointegrating vectors in higher order integrated systems," Econometrica: Journal of the Econometric Society, pp. $783-820.9$

Stone, A.-L., B. E. Gup, and J. Lee (2013): "Corporate Cash Holdings and Interest Rates: 1970-2011," Discussion paper, Working Paper. 2

Teles, P., And R. Zhou (2005): "A stable money demand: Looking for the right monetary aggregate," Economic Perspectives - Federal Reserve Bank of Chicago, 29(1), 50. 9, 13

ToBin, J. (1956): "The interest-elasticity of transactions demand for cash," The Review of Economics and Statistics, 38(3), 241-247. 11 


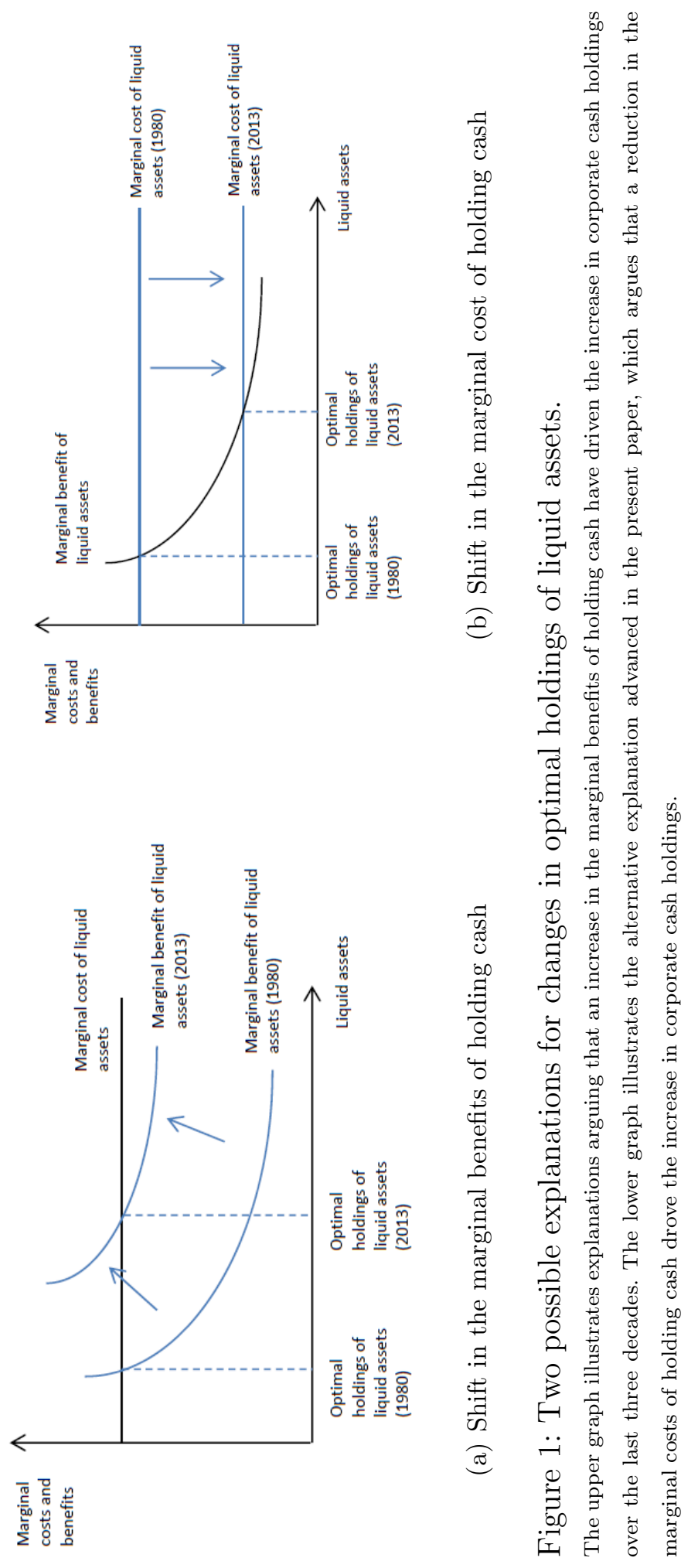




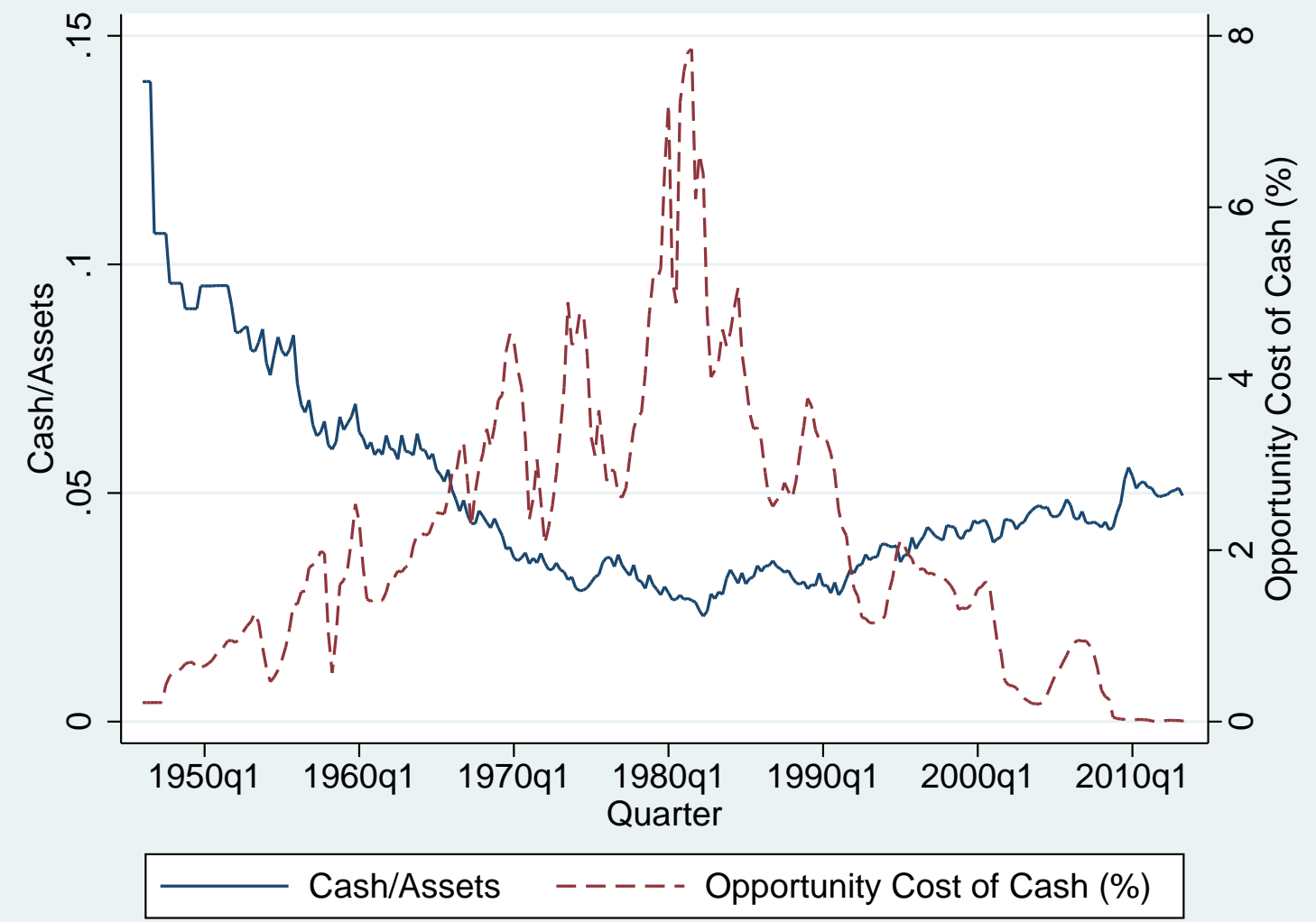

Figure 2: Cash-to-asset ratio and opportunity costs of cash.

The aggregate cash-to- assets ratio is calculated for the nonfinancial corporate sector using Fed flow of funds data from 1945 to 2013 as the sum of currency and checking deposits, time and savings deposits, money market mutual fund accounts, government securities, and mutual fund shares, divided by total assets. The opportunity cost of holding liquid assets is calculated as the spread between the three-month T-Bill rate and the rate of return on the portfolio of liquid assets held by the corporate sector. To approximate the return on the liquid assets portfolio of the nonfinancial corporate sector, we use Fed flow of funds data on the composition of liquid assets for the sector to calculate a rolling 20-year average of the share of liquid assets held in currency and checking accounts. We assume the currency and checking component of the liquid assets portfolio has a zero nominal return. We proxy for the risk-adjusted return on all other components using the nominal three-month T-Bill rate. 

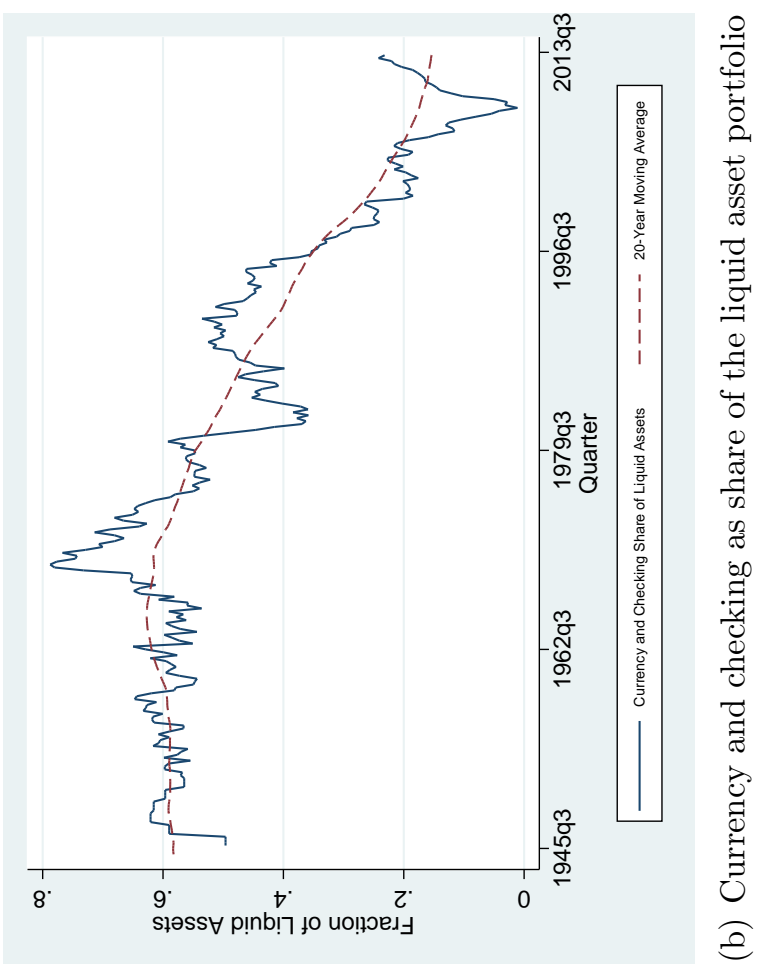

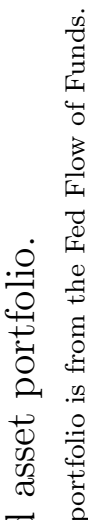

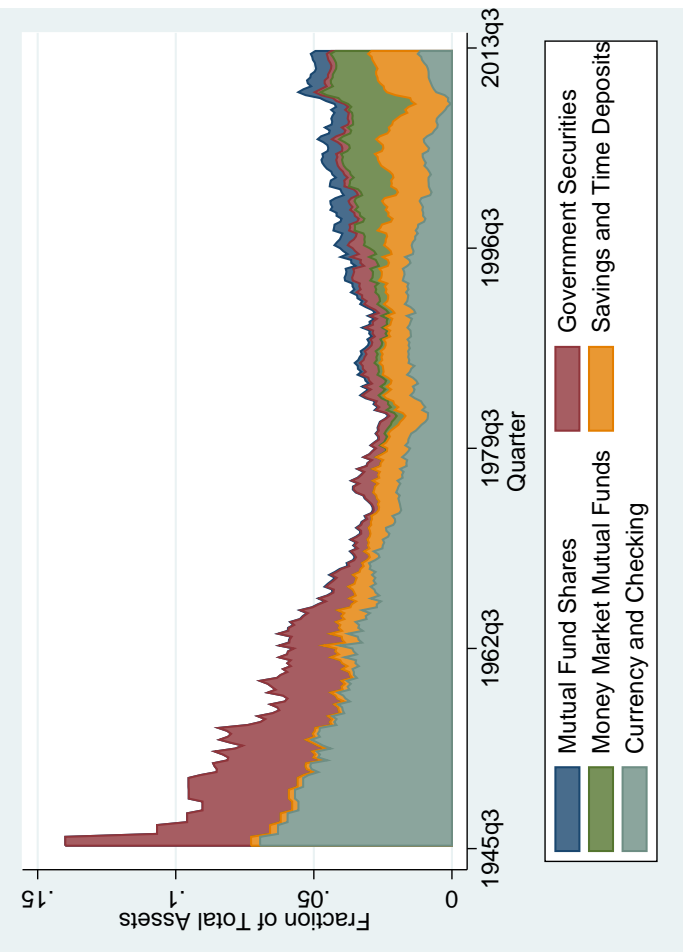

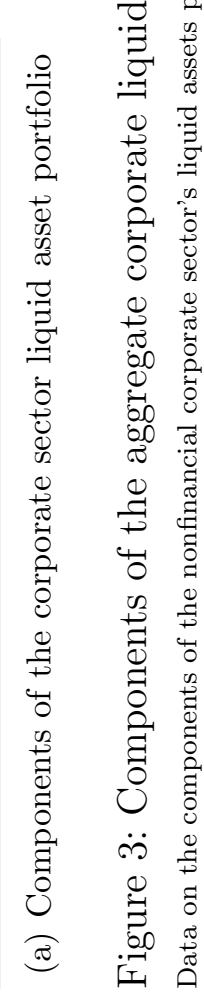




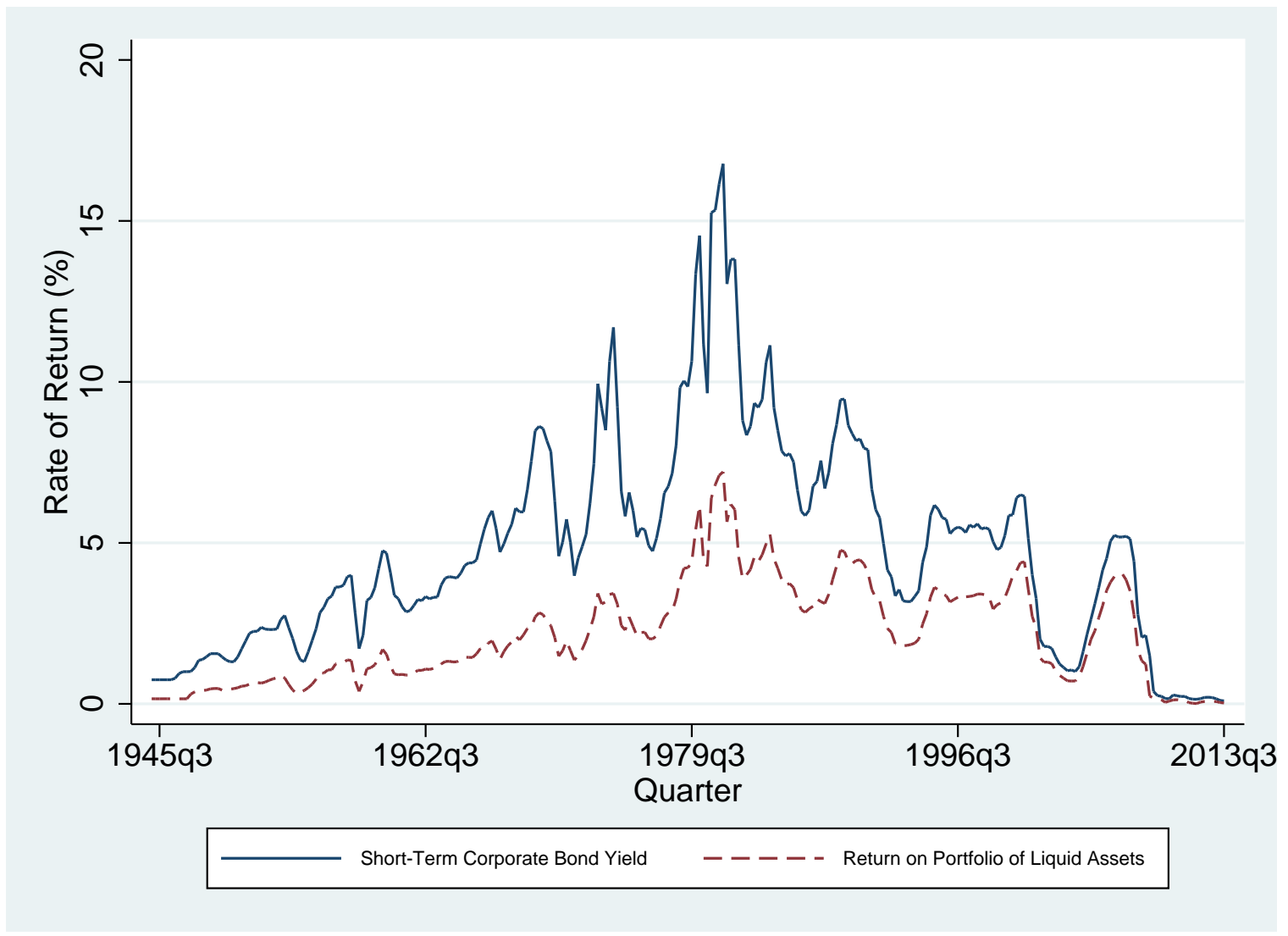

Figure 4: T-Bill return and return of the aggregate corporate liquid asset portfolio.

Data on the components of the nonfinancial corporate sector's liquid assets portfolio is from the Fed Flow of Funds. The T-Bill approximates the cost of capital o the corporate cash portfolio. To approximate the return on the liquid assets portfolio of the nonfinancial corporate sector, we use Fed flow of funds data on the composition of liquid assets for the sector to calculate a rolling 20-year average of the share of liquid assets held in currency and checking accounts. We assume the currency and checking component of the liquid assets portfolio has a zero nominal return. We proxy for the risk-adjusted return on all other components using the nominal three-month T-Bill rate. The wedge between cost and return of the cash portfolio (the difference between the blue and red line in the graph) is the opportunity cost of holding cash. 

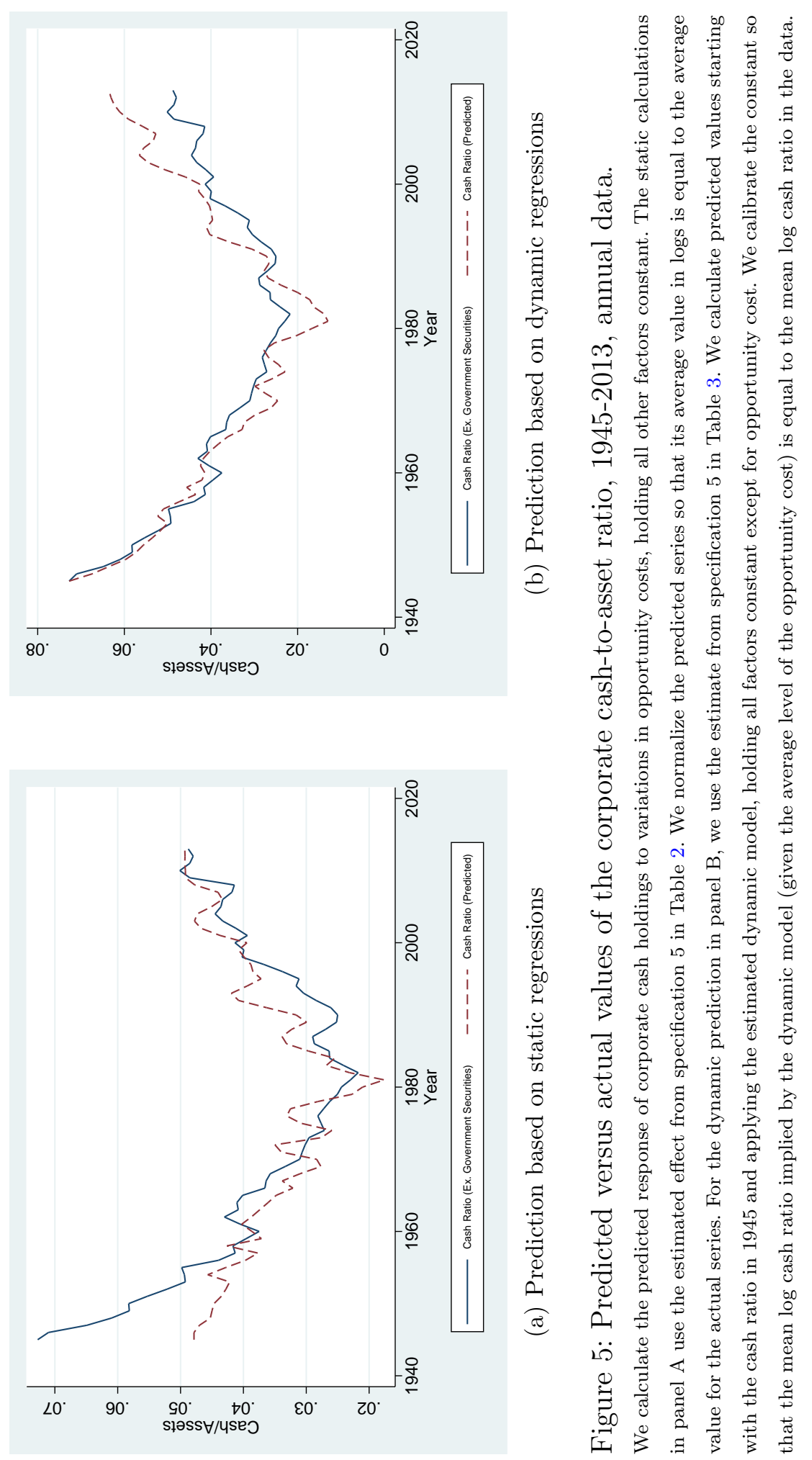


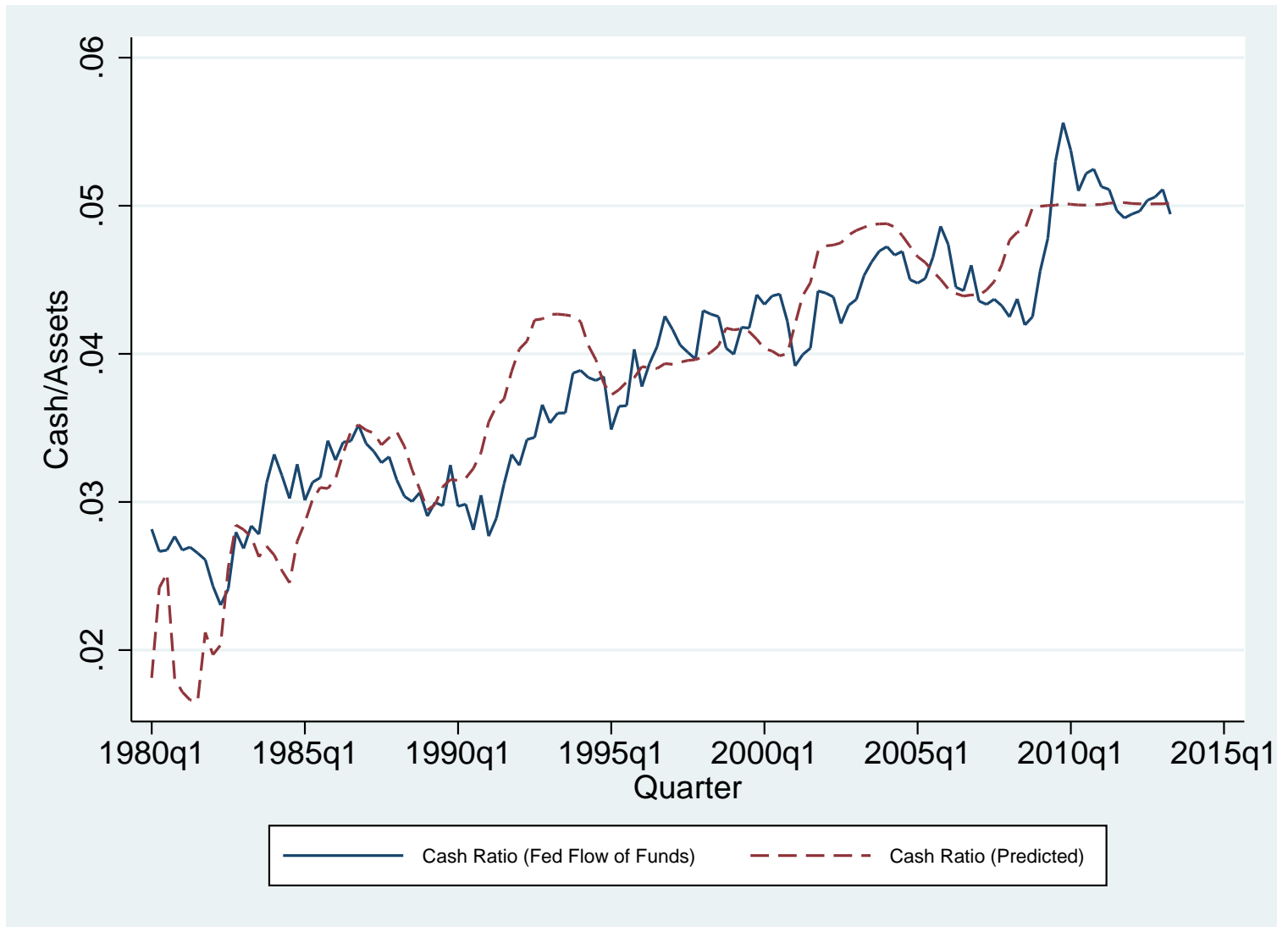

Figure 6: Predicted versus actual cash-to-asset ratio, 1980-2013, quarterly data.

We calculate the predicted response of corporate cash holdings to variations in opportunity costs, holding all other factors constant. The calculations use the estimated effect from specification 5 in Table 2. We normalize the predicted series so that its average value in logs is equal to the average value for the actual series. 


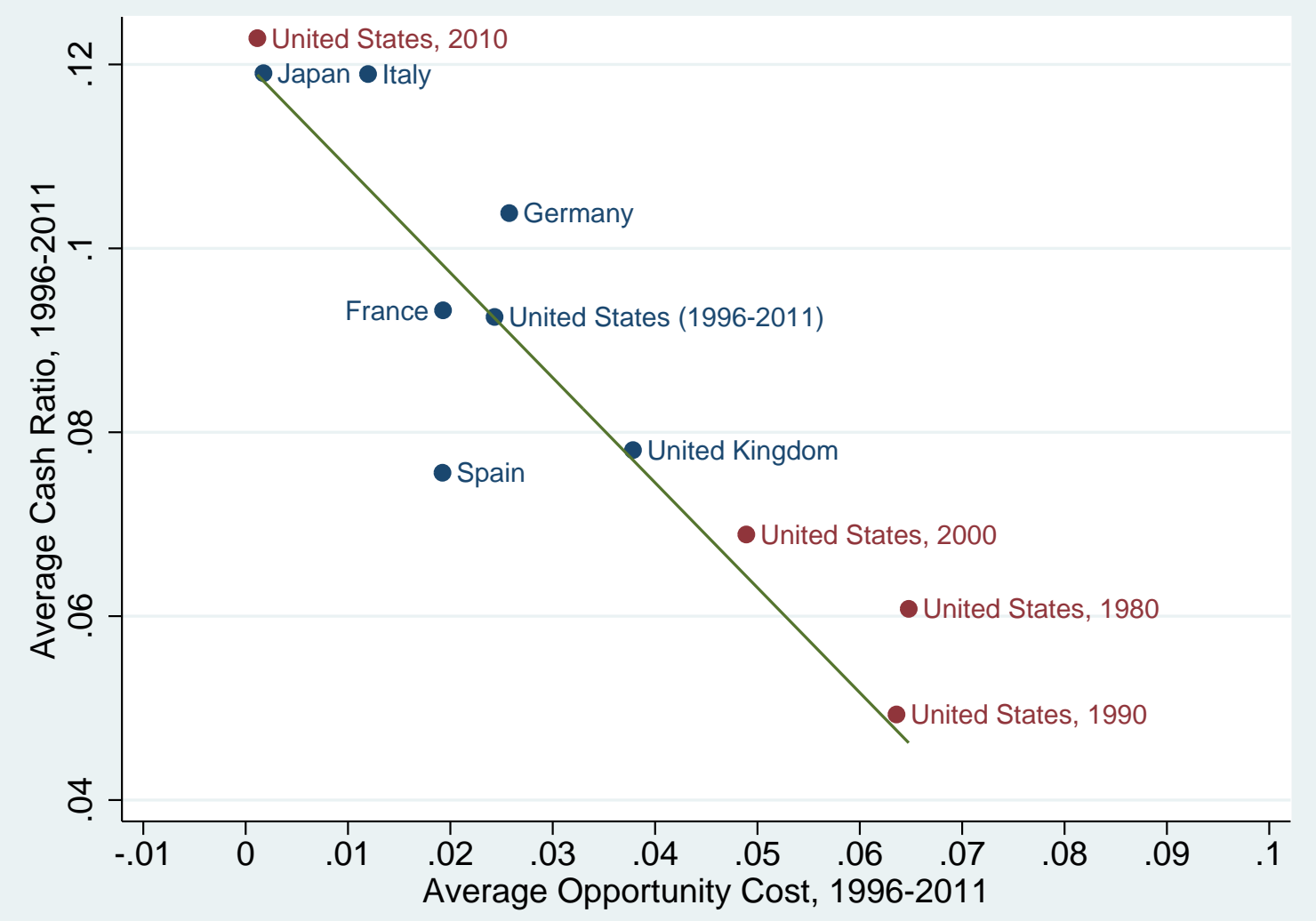

Figure 7: Average cash-to-asset ratio versus average opportunity cost, by country.

The sample includes all Compustat North America and Compustat Global firm-year observations between 1996 and 2011. We exclude from the sample: (i) financial firms (SIC code 6000-6999) and utilities (SIC codes 4900-4999), and (ii) firms with non-positive values for book value of total assets or sales revenue. Firms with less than 10 years of observations are excluded from the sample. We first calculated an asset-weighted average of the cash to assets ratio and of opportunity cost for each country-year. Then we average across years. Regression line is estimated using only country averages for the period 1996-2011. 


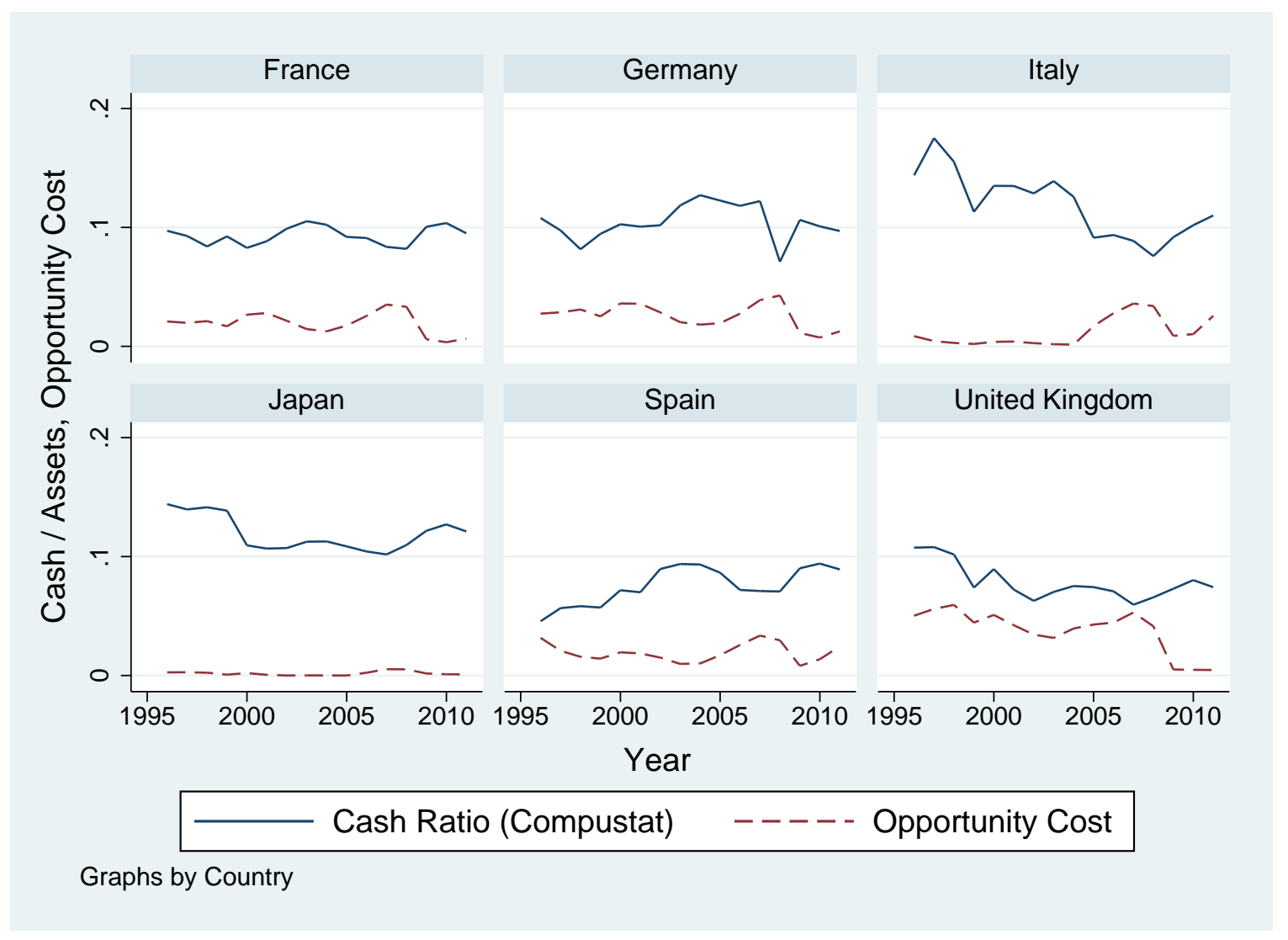

Figure 8: Cash-to-asset ratio and opportunity cost over time, by country.

The sample includes all Compustat North America and Compustat Global firm-year observations between 1996 and 2011. We exclude from the sample: (i) financial firms (SIC code 6000-6999) and utilities (SIC codes 4900-4999), and (ii) firms with non-positive values for book value of total assets or sales revenue. Firms with less than 10 years of observations are excluded from the sample. The cash ratio is calculated as an asset-weighted average of the cash to assets ratio for each country-year. Opportunity cost is caluclated as the country's interest rate times the average fraction of cash that is held in immediately negotiable media of exchange. Interest rate data on three-month interest rates is from FRED. We use treasury bill rates for all countries except Germany, for which we use the 90-day interbank lending rate, because it is available for a longer timer period. 


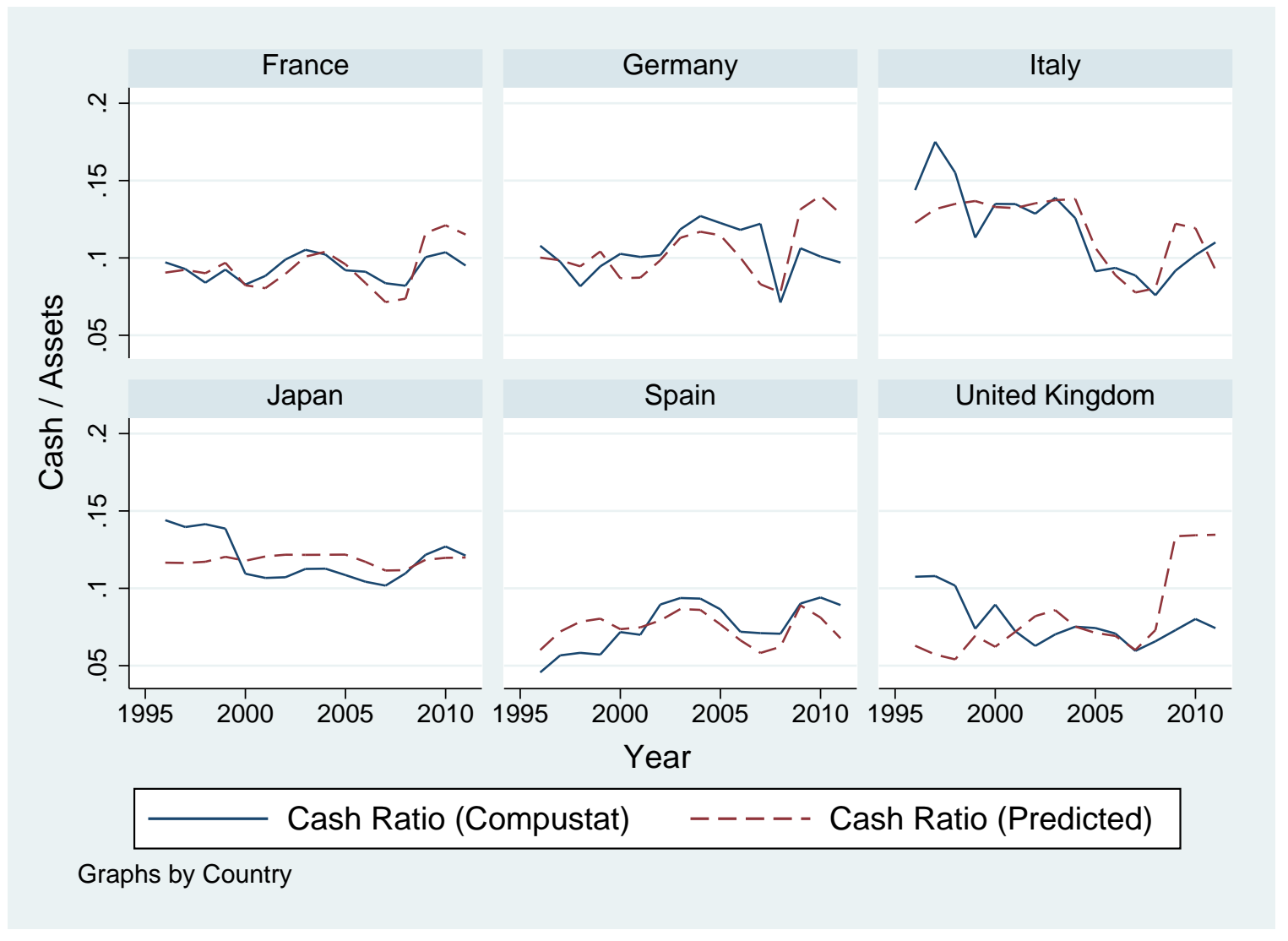

Figure 9: Predicted versus actual cash-to-asset ratio, 1996-2011, by country.

We calculate the predicted response of corporate cash holdings to variations in opportunity costs, holding all other factors constant. The static calculations use the estimated effect from specification 9 in Table 7 . For each country, we normalize the predicted series so that its average value in logs is equal to the average value for the actual series. 
Table 1: Summary statistics for firm-level variables.

The sample includes all Compustat firm-year observations between 1980 and 2011, except (i) financial firms (SIC code 60006999) and utilities (SIC codes 4900-4999), (ii) firms not incorporated in the United States, and (iii) firms with non-positive values for book value of total assets or sales revenue. Variable definitions are provided in the appendix.

\begin{tabular}{lccccc}
\hline Variable & Mean & Std. Dev. & Min. & Max. & N \\
\hline Cash / Assets & 0.178 & 0.214 & 0 & 1 & 131694 \\
Total Assets (in millions of 2005 USD) & 1655.815 & 11573.645 & 0.004 & 775485.375 & 131694 \\
Industry Sigma & 0.083 & 0.04 & 0.013 & 0.207 & 131651 \\
Cash Flow / Assets & 0.003 & 0.213 & -1.021 & 5.271 & 123749 \\
NWC / Assets & 0.1 & 0.209 & -0.547 & 0.923 & 127818 \\
R\&D / Sales & 0.172 & 0.723 & 0 & 5.350 & 131694 \\
Dividend Dummy & 0.305 & 0.461 & 0 & 1 & 131694 \\
Market to Book & 2.02 & 1.731 & 0.122 & 10.839 & 130957 \\
Capex & 0.069 & 0.075 & 0 & 0.408 & 130146 \\
Leverage & 0.234 & 0.219 & 0 & 1 & 131239 \\
Acquisition Activity & 0.021 & 0.057 & -0.002 & 0.328 & 126119 \\
\hline
\end{tabular}




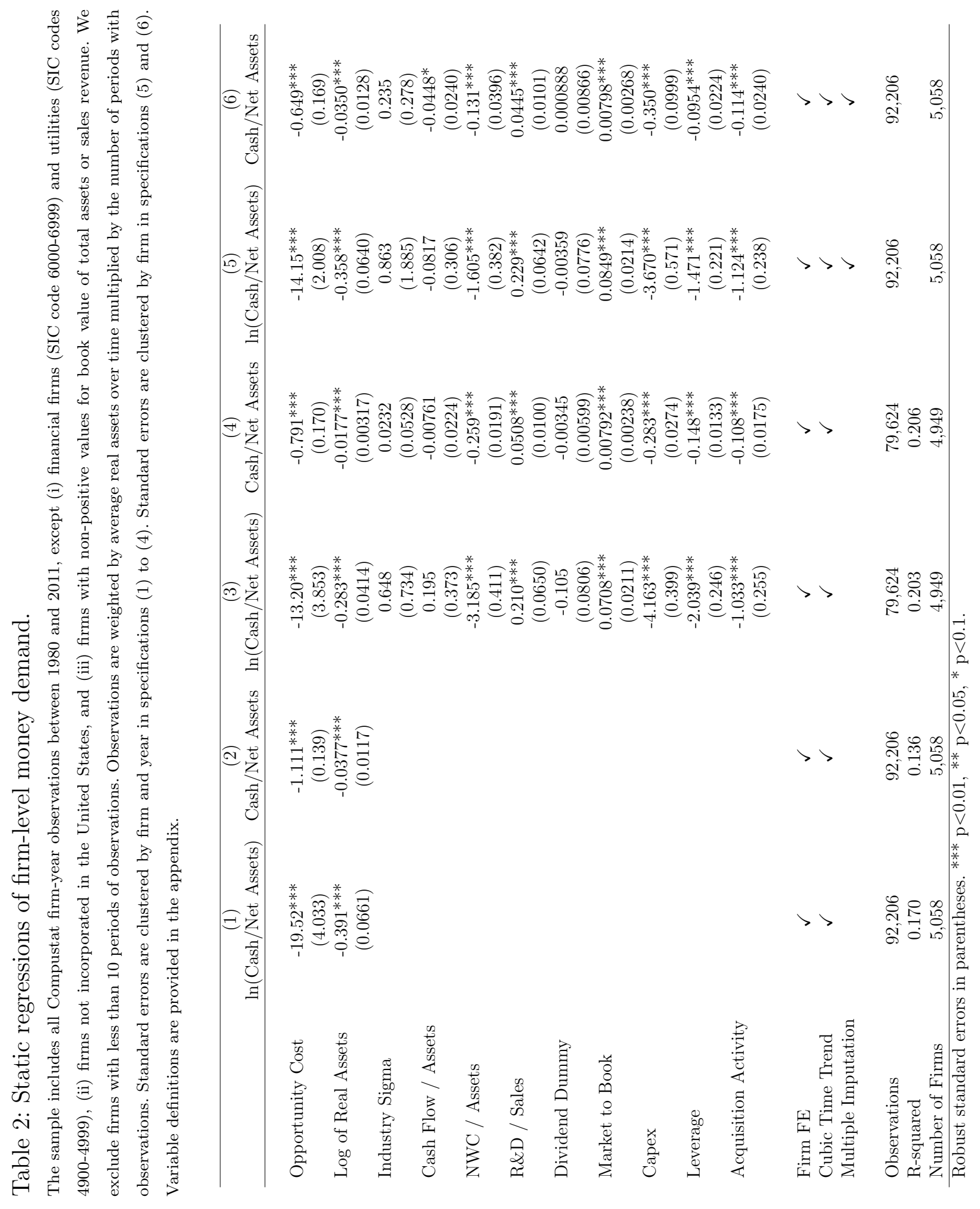




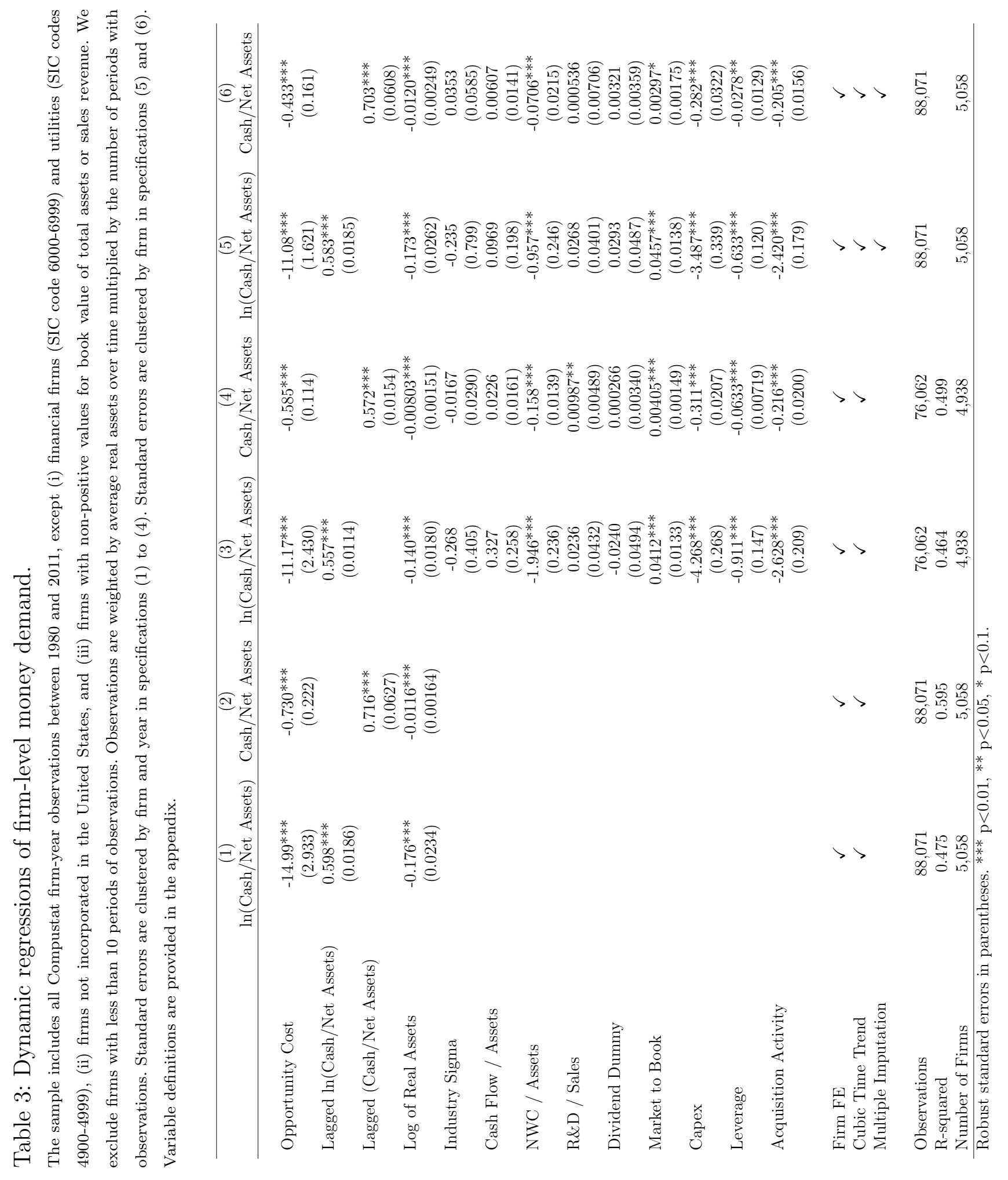




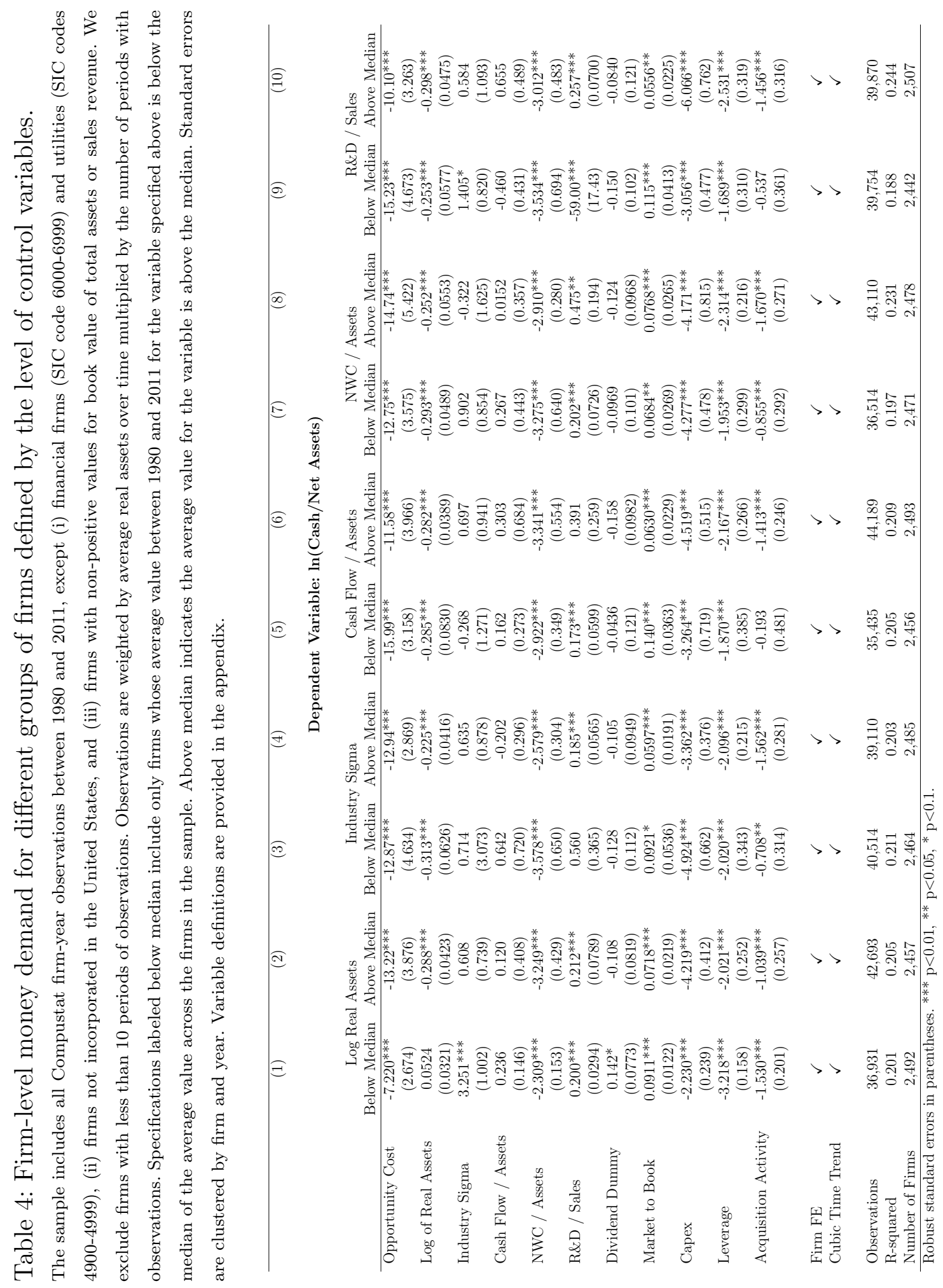




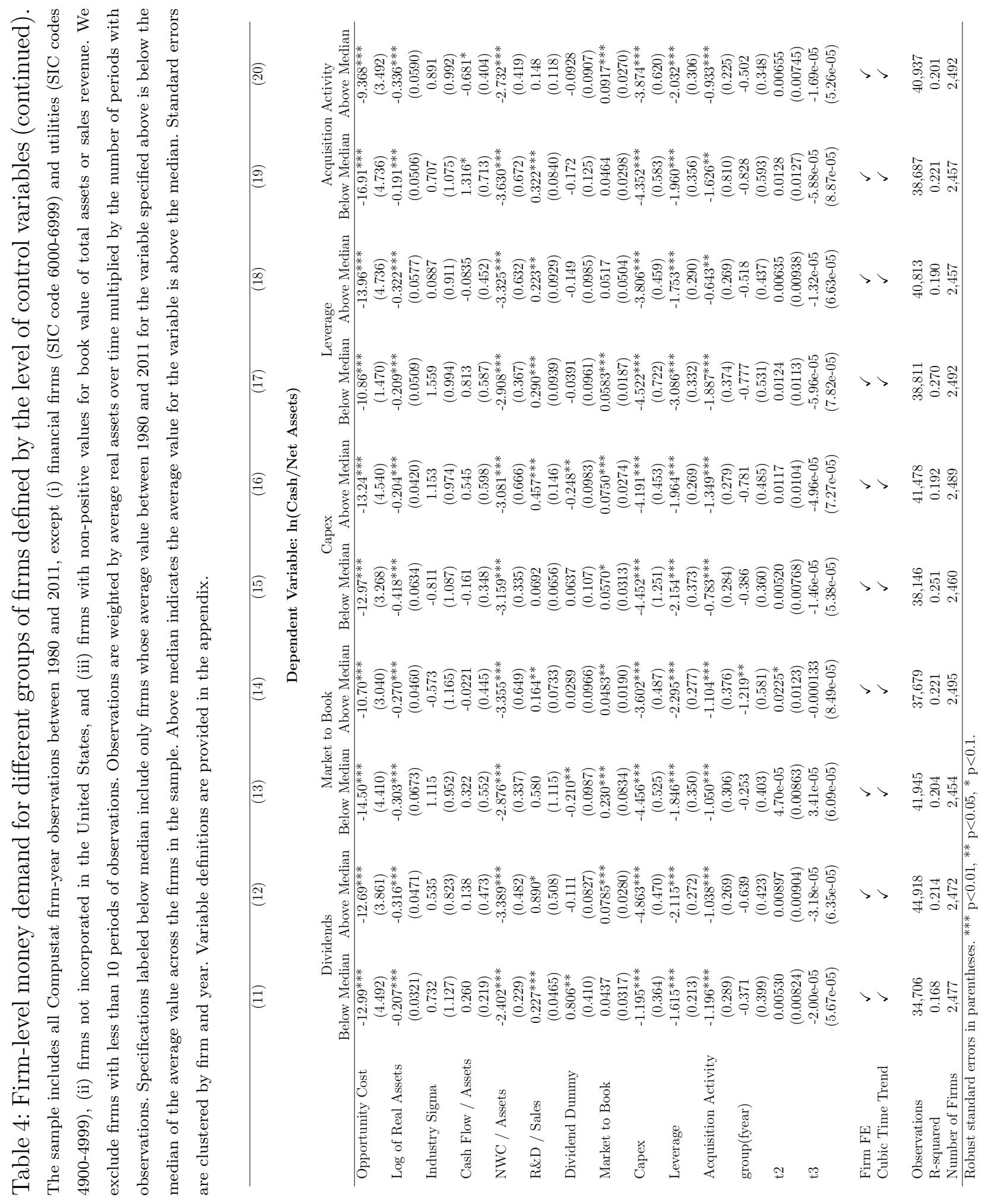


Table 5: Firm-level money demand by SIC industry definition.

The sample includes all Compustat firm-year observations between 1980 and 2011, except (i) financial firms (SIC code 60006999) and utilities (SIC codes 4900-4999), (ii) firms not incorporated in the United States, and (iii) firms with non-positive values for book value of total assets or sales revenue. We exclude firms with less than 10 periods of observations. Observations are weighted by average real assets over time multiplied by the number of periods with observations. Standard errors are clustered by firm and year. Variable definitions are provided in the appendix.

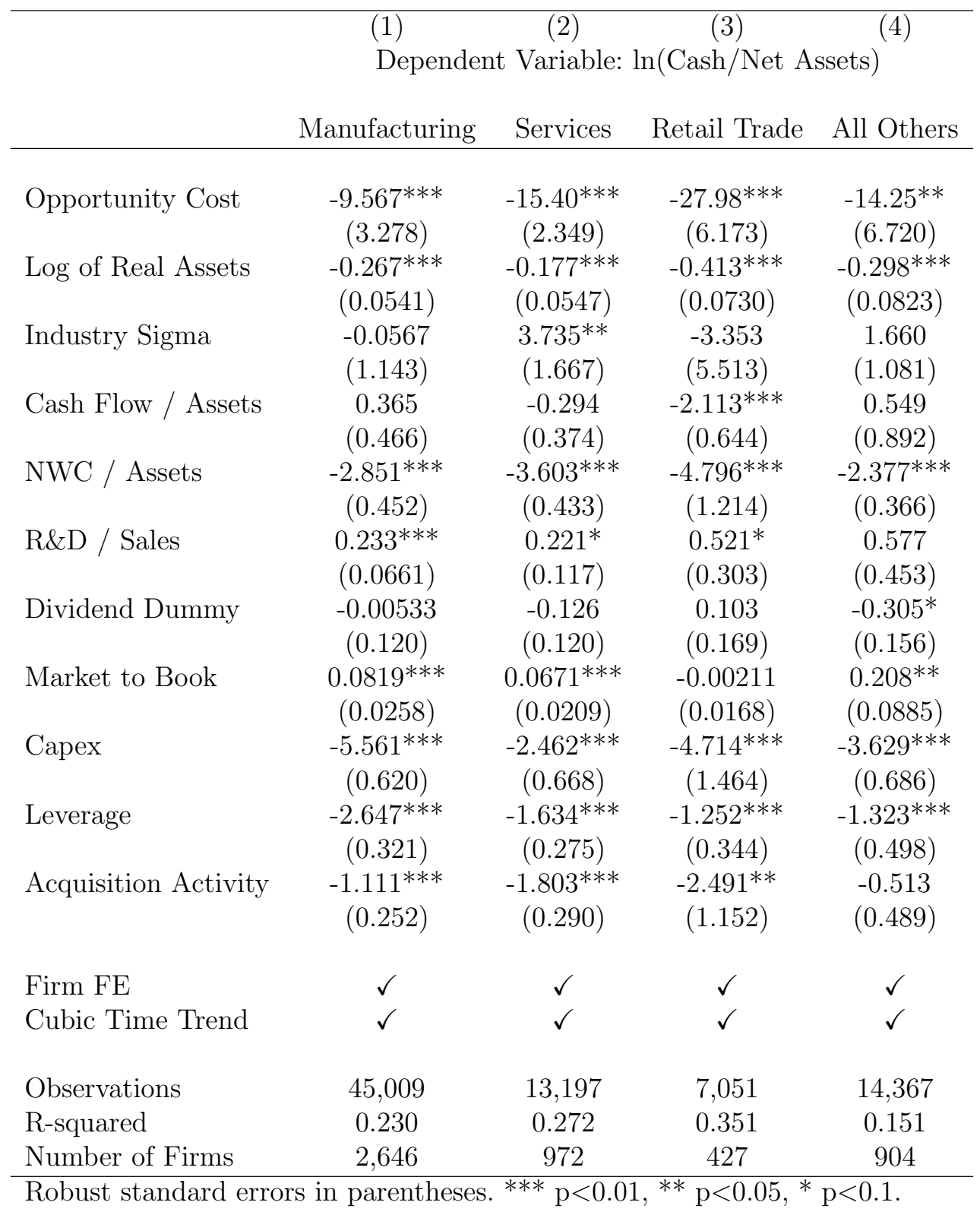




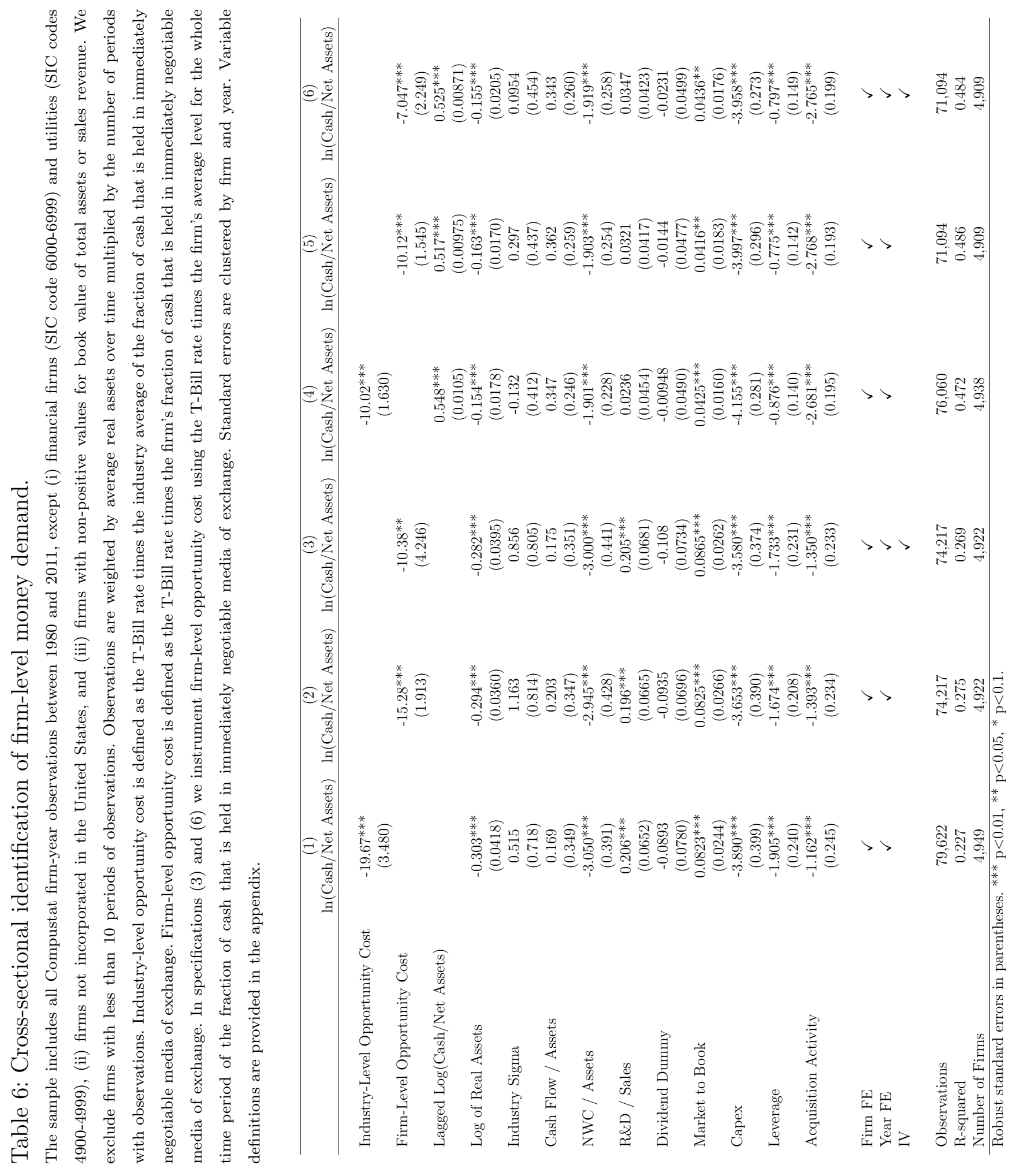




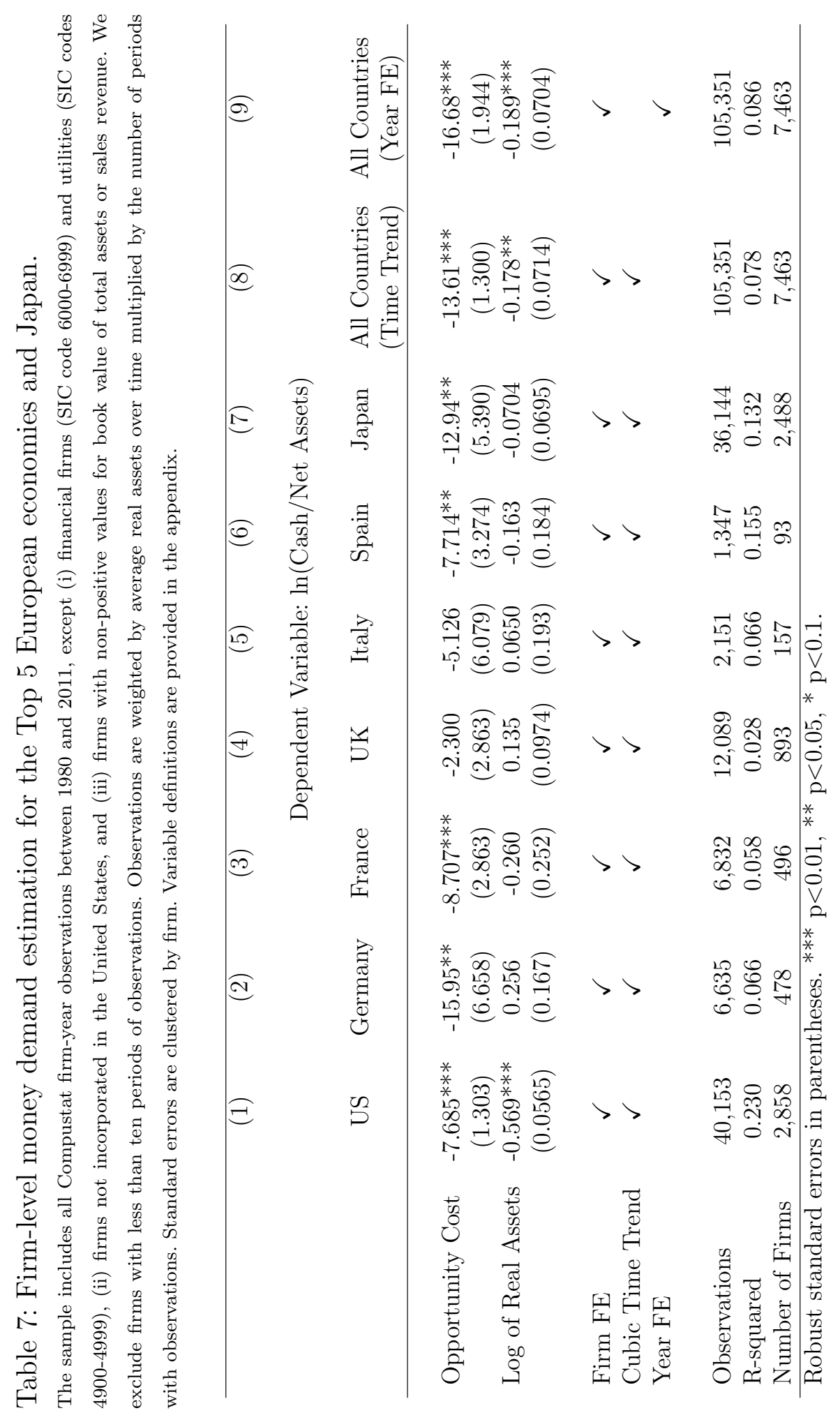




\section{A Apendix: Variable Definitions}

\section{A.1 Control variable definitions}

Numbers in brackets correspond to the variable numbers in the Compustat database.

- Acquisition Activity: ratio of acquisitions [\#129] to total book assets [\#6].

- Capex: ratio of capital expenditures [\#128] to total book assets [\#6].

- Cash/Assets: ratio of cash and short-term investments [\#1] to total book assets [\#6].

- Cash/Net Assets: ratio of cash and short-term investments [\#1] to net assets, where net assets equal total book assets [\#6] minus cash holdings [\#1].

- Cash Flow/Assets: ratio of operating income before depreciation [\#13], after interest [\#15], dividends [\#21] and taxes [\#16] to total book assets [\#6].

- Dividend Dummy: indicator variable equal to 1 if a firm paid a common dividend in a given year (i.e., \#21 is positive).

- Industry Sigma: volatility of cash flow to assets within the two-digit SIC group of a firm. As in Bates, Kahle, and Stulz (2009), for a given year and two-digit SIC group, we calculate the standard deviation of Cash Flow / Assets over the previous 10 years for each firm within that group. A firm must have at least three observed Cash Flow/Assets over the previous 10 years in order to be counted. Industry Sigma for a two-digit SIC group is the average of the standard deviations of Cash Flow/Assets across all firms in the group.

- Leverage: ratio of the sum of long-term debt [\#9] and debt in current liabilities [\#34] to total book assets $[\# 6]$. 
- Market to Book: ratio of the market value of the firm to total book asset value [\#6]. Market value is proxied as book value of assets [\#6] plus market value of equity (equal to the stock price at fiscal year close [\#199] times the number of common shares outstanding [\#25]) less book value of common equity [\#60].

- NWC/Assets: ratio of net working capital, net of cash and short-term investments [\#179-\#1], to total book assets [\#6].

- Opportunity Cost: spread between the T-Bill rate and the return on the nonfinancial corporate sector's liquid assets portfolio. The return on the nonfinancial corporate sector's liquid assets portfolio equals the nominal three-month T-Bill rate times 1 minus the share of liquid assets held in currency and checking accounts by the sector. For the time-series identification, in any given year, the share of liquid assets held in currency and checking accounts is calculated as a rolling 21-year average of annual ratios of the sector's holding of currency and checking accounts to total liquid assets holdings. Data on the corporate sector's cash holdings are from the Fed Flow of Funds. For the cross-sectional identification, the return on the firm's liquid asset portfolio is the sum of non-interest bearing cash $(\mathrm{CH})$ multiplied with zero return and interestbearing cash (CHE-CHE) multiplied with the T-Bill rate. In sum, the opportunity cost is the cash held in non-interest bearing cash multiplied with the T-Bill rate.

- R\&D / Sales: ratio of R\&D expenditures [\#46] to sales [\#12]. When missing from Compustat, $R \& D$ is set equal to 0 .

- Real Assets: ratio of total book assets [\#6] to the US GDP deflator in the corresponding year (equal to 100 in 2005) divided by 100. The US GDP deflator is obtained from FRED. 
- Total Assets: book value of total assets [\#6].

\section{A.2 Compustat definition of the $\mathrm{CH}$ and $\mathrm{CHE}$ variables}

- $\mathrm{CH}$ includes

- 1. Bank drafts

- 2. Banker's acceptances

- 3. Cash

- 4. Certificates of deposit included in cash by the company

- 5. Checks (cashiers or certified)

- 6. Demand certificates of deposit

- 7. Demand deposits

- 8. Letters of credit

- 9. Money orders

- CHE includes all items included in $\mathrm{CH}$, plus

- 1. Accrued interest combined with short-term investments

- 2. Brokerage firms' good faith and clearing-house deposits

- 3. Cash in escrow

- 4. Cash segregated under federal and other regulations

- 5. Certificates of deposit included in short-term investments by the company

- 6. Certificates of deposit reported as a separate item in current assets 
- 7. Commercial paper

- 8. Gas transmission companies' special deposits

- 9. Government and other marketable securities (including stocks and bonds listed as shortterm)

- 10. Margin deposits on commodity futures contracts

- 11. Marketable securities

- 12. Money-market fund

- 13. Repurchase agreements shown as a current asset

- 14. Real estate investment trusts shares of beneficial interest

- 15. Restricted cash shown as a current asset

- 16. Term deposits

- 17. Time deposits and time certificates of deposit (savings accounts shown in current assets)

- 18. Treasury bills listed as short-term 
B Appendix: Figures and Tables 


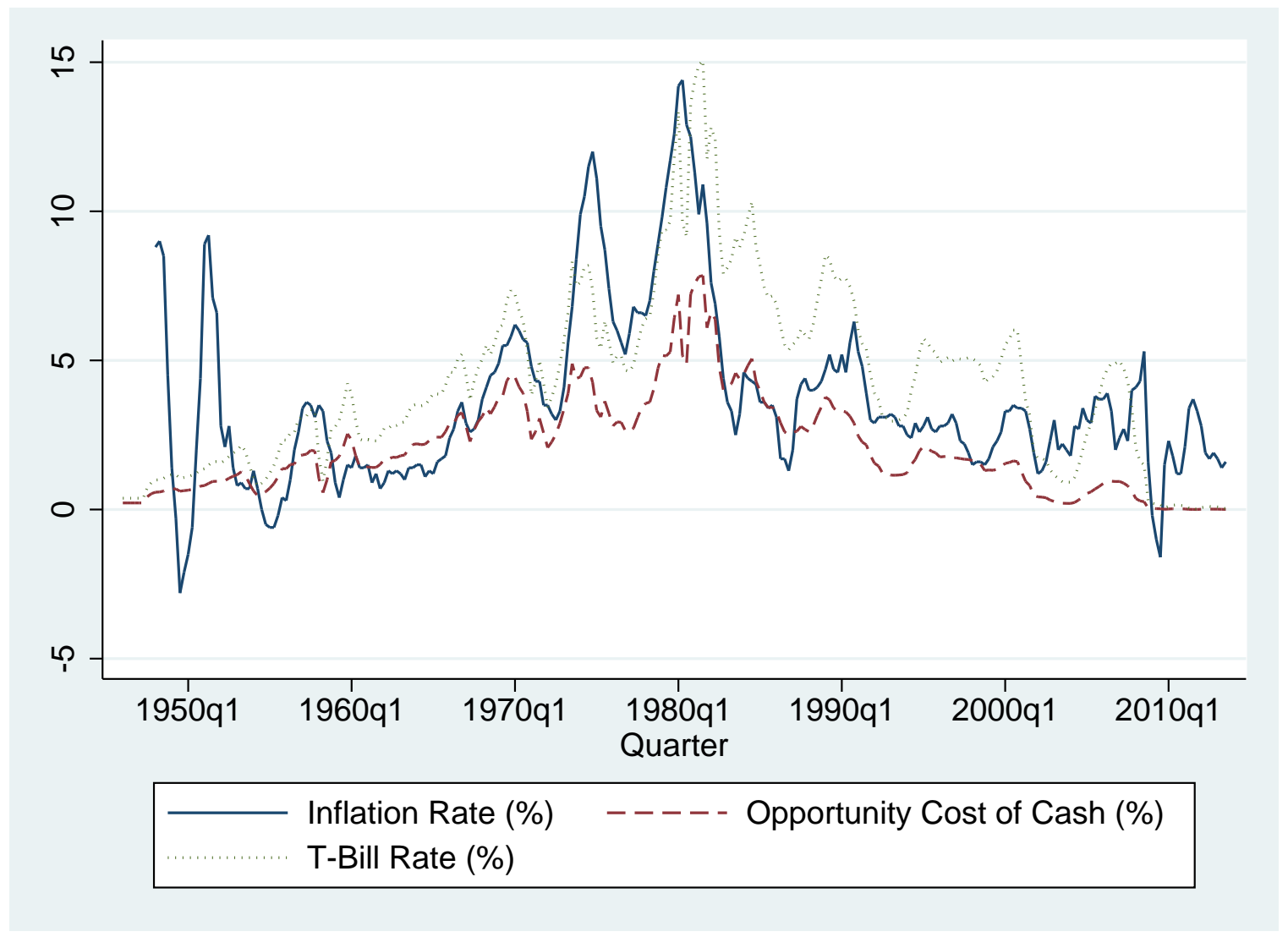

Figure B.1: Inflation Rate, Nominal Interest Rate, and Opportunity Cost of Cash, 1945-2013. The inflation rate is calculated as the percentage change in the consumer price index for all urban consumers with respect to the same quarter in the previous year. The T-Bill rate refers to the rate on 3-month US Treasury bills. The opportunity cost of holding liquid assets is calculated as the spread between the three-month T-Bill rate and the rate of return on the portfolio of liquid assets held by the corporate sector. To approximate the return on the liquid assets portfolio of the nonfinancial corporate sector, we use Fed flow of funds data on the composition of liquid assets for the sector to calculate a rolling 20-year average of the share of liquid assets held in currency and checking accounts. We assume the currency and checking component of the liquid assets portfolio has a zero nominal return. We proxy for the risk-adjusted return on all other components using the nominal three-month T-Bill rate. 


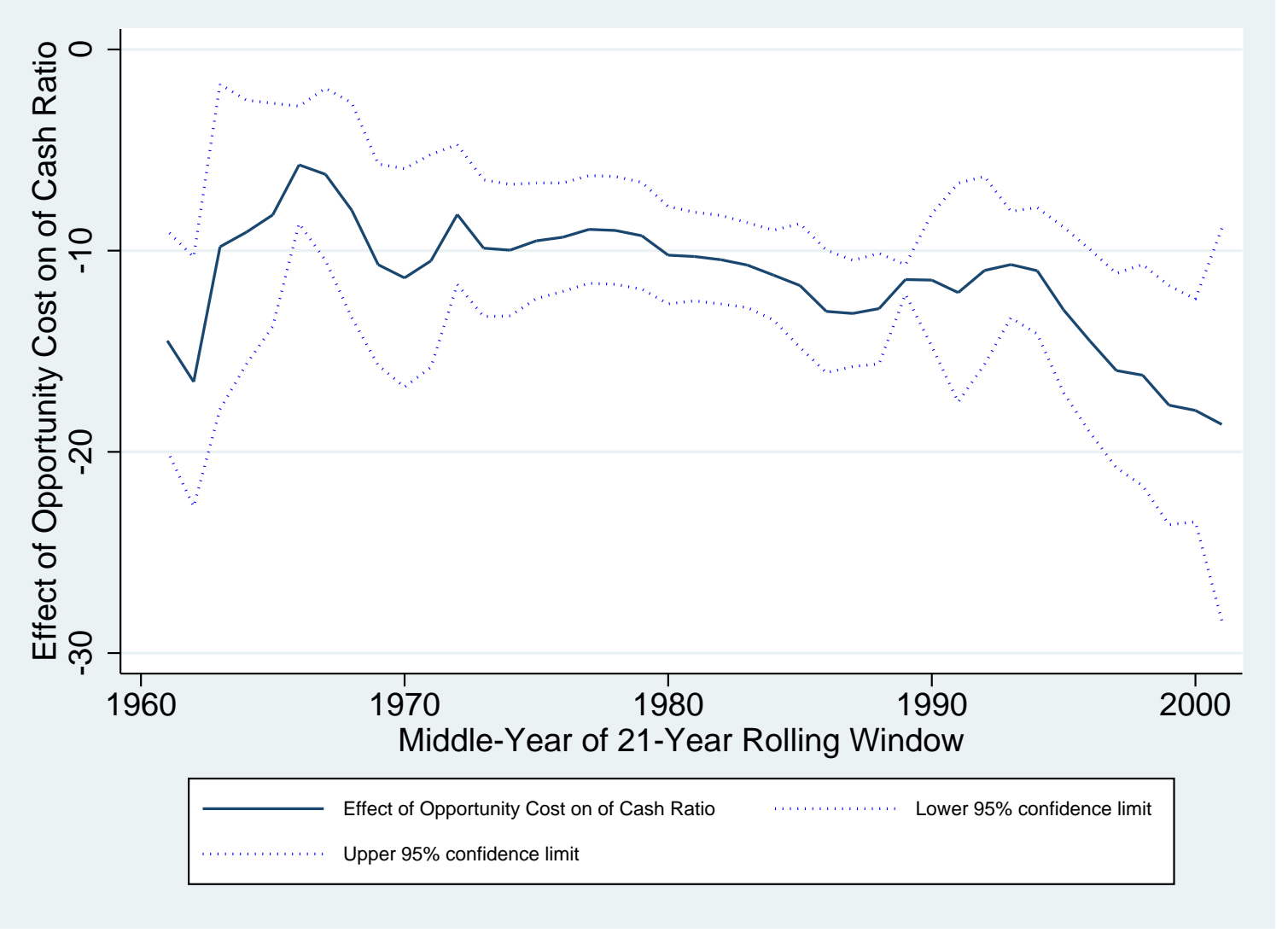

Figure B.2: Rolling Regressions of Firm-Level Money Demand.

The estimated effects of the opportunity cost on the cash ratio are based on rolling regressions of the log cash ratio as a function of opportunity cost, log of assets, a cubic time trend, and firm fixed effects. The window includes ten years before and ten years after the year indicated in the $\mathrm{x}$ axis. Firms with less than 10 observations over the window are excluded. Regressions are estimated by WLS, with firms weighted by average assets multiplied by number of periods with observations. Standard errors are clustered at the firm and year level. 


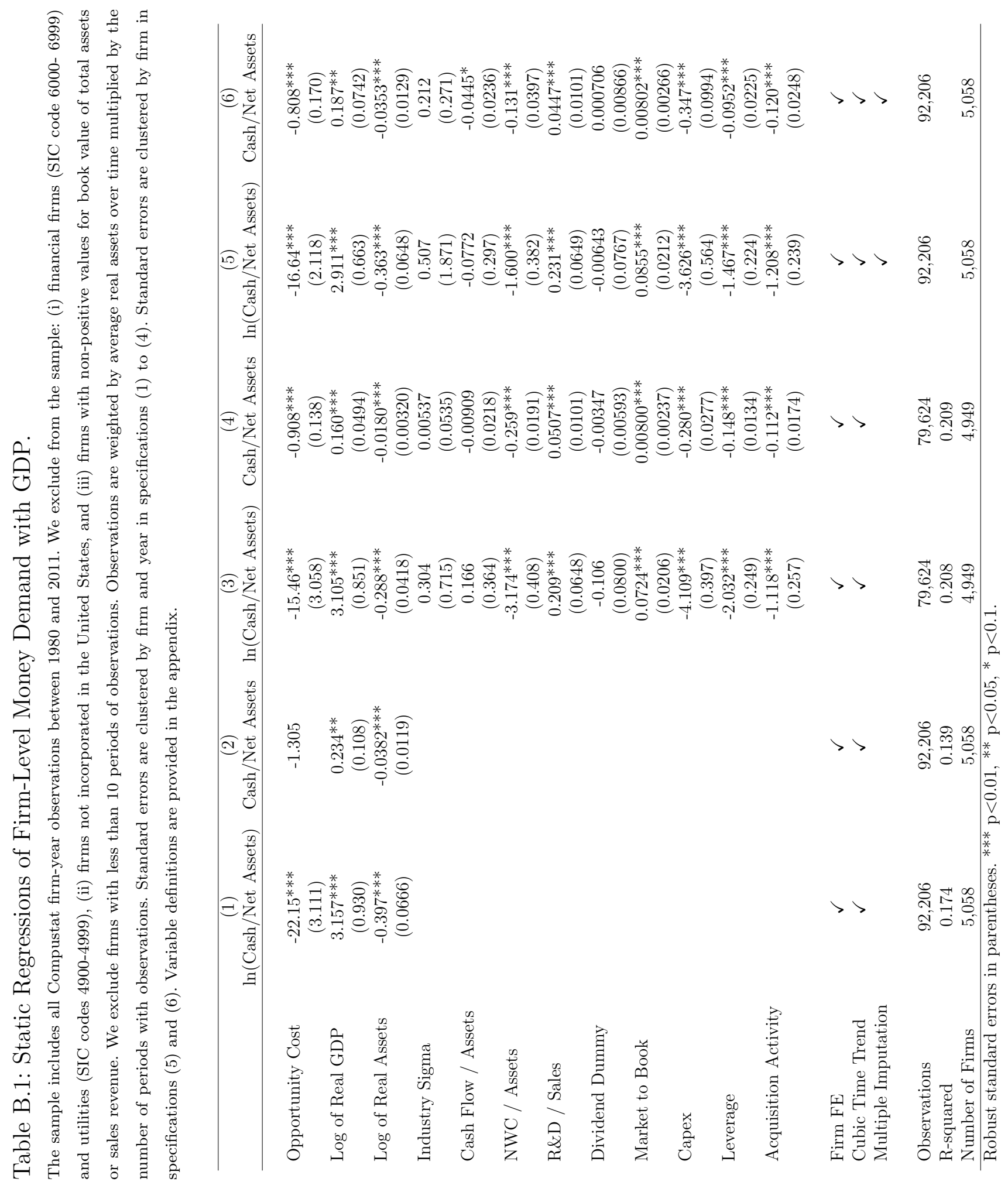




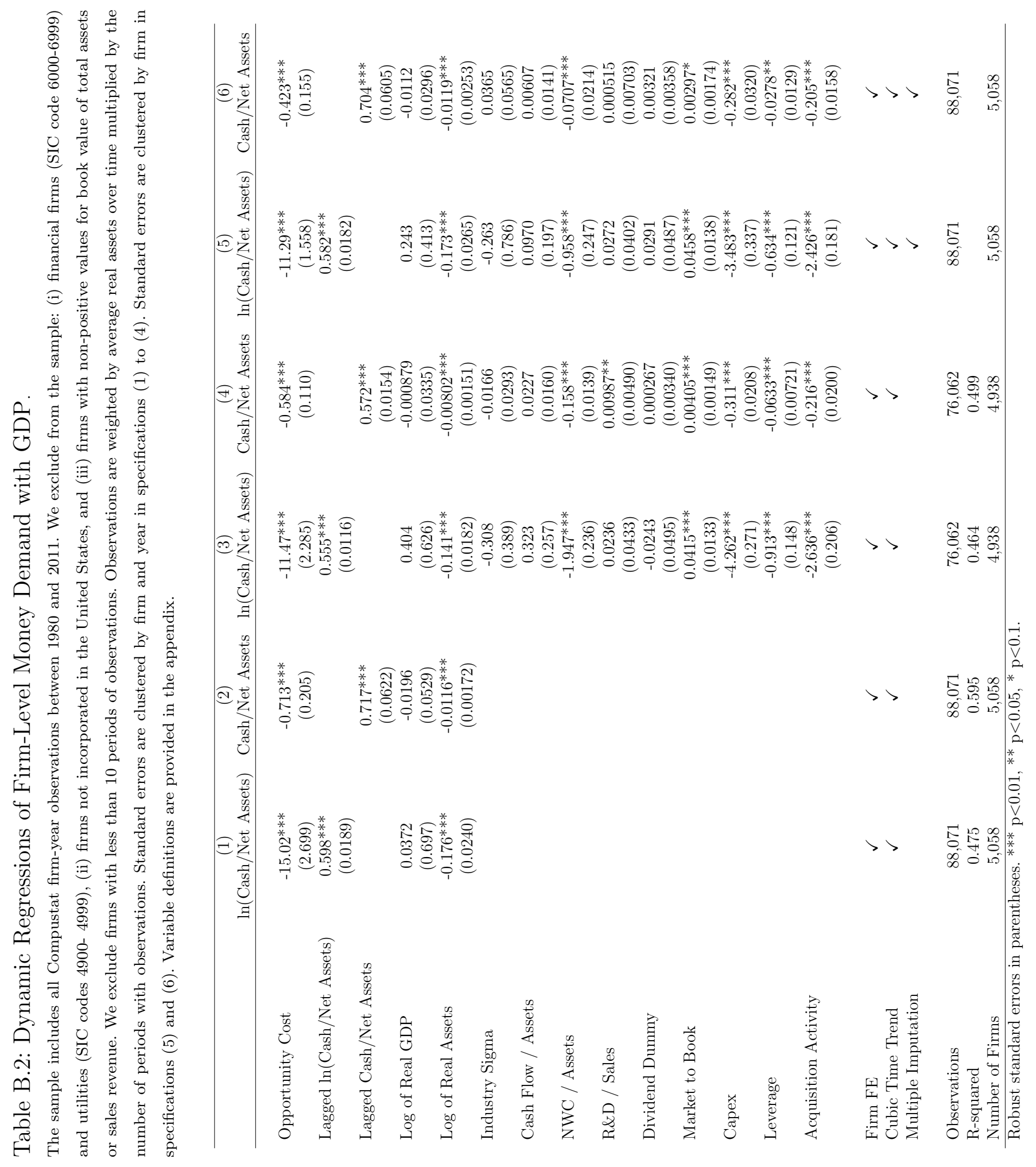

